\title{
X-ray evaluation at 5-6 years of Straumann implants (part 1)
}

\author{
Hamasat Gheddaf-Dam ${ }^{1, \star}$, Semaan Abi Najm², Stella Lysitsa ${ }^{3}$, Mark Bischof², \\ Rabah Nedir ${ }^{2}$ \\ 1 Department of Prosthodontics and Operative Dentistry, Tufts School of Dental Medicine Boston, USA \\ 2 Division of Stomatology and Oral Surgery, Dental School, Geneva, Switzerland \\ 3 Department of Oral Surgery, Aristotle University, Thessaloniki, Greece
}

(Received 21 September 2009, accepted 8 0ctober 2009)

Key words:

implant /

biomedical factors /

private practice

\begin{abstract}
The loss of bone around implants is, on an average, below $1 \mathrm{~mm}$ during the first year and $0.2 \mathrm{~mm}$ per year in the years that follow. It essentially depends upon biomechanical factors but the level at which the bone stabilizes is determines by the implant depth.

Intraoral radiographs (paralleling technique) are considered as the "firs choice2 for the evaluation of the radiolucency with respect to the proximal peri-implant bone.

This study was based on 528 implants placesd in private practice, with an objective to determine their success rate and their survival at 5-6 years, to evaluate the peri-implant proximal bone loss and outline the factors that could influence this bone loss.

The results obtained from 411 accessible patient files are in accordance with the literature date (at 5- 6 years, the survival rate is $99.2 \%$, the success rate is $93 \%$, the average bone los sis $1.16 \mathrm{~mm}$ ). The bone loss was more severe in smokers and in implants with a TPS surface, those placed in the anterior regions or those with vestibular cortical bone below the $1 \mathrm{~mm}$. Short implants were not associated with a more severe bone loss than longer implants.
\end{abstract}

\section{Introduction}

Implant therapy has long been proven to be a safe and reliable mode of treatment with a limited number of biological and prosthetic postoperative complications [1]. Since the early studies of Brånemark et al. [2], osseointegrated implants have become the therapy of choice to rehabilitate edentulous ridges. Success rates are very high, as proven by the longitudinal studies of Adell et al. $[3,4]$

Concise success criteria were established in earlier studies. They stated that the vertical bone loss at the implant crestal sites should, on average, be less than $1.0 \mathrm{~mm}$ following the first year of implants in function, and should not exceed $0.2 \mathrm{~mm}$ in subsequent years $[5,6]$. Other parameters such as the absence of continuous radiolucency around the implants, lack of mobility, assessment of the degree of inflammation, gingival recession and pocket probing depths were also included in the classification of success criteria [5]. Later on, the definition of success was simplified by Buser et al. [7] as the following:

1. Absence of persistent subjective complaints, such as pain, foreign body sensation and/or dysthesia,

\footnotetext{
*Correspondence: hamasat.gheddaf_dam@tufts.edu
}

2. Absence of recurrent peri-implant infection with suppuration,

3. Absence of mobility.

These criteria were used in the present study for the determination of success and survival rates for a population of 528 Straumann ${ }^{\circledR}$ implants, over a period of 5-6 years. A radiological bone level evaluation was also performed at the end of the study period, and was included in the determination of the success criteria. The following sections explain and justify the methods and principles of this evaluation. The introduction concludes with an overview of the external factors that might influence the peri-implant bone level, which was considered in the current study.

\section{Crestal bone remodeling}

Comprehension of the physiological principles governing crestal bone remodeling around implants facilitates the distinction between an expected physiologic crestal bone remodeling, and a pathologic condition resulting in bone loss [8]. Hermann et al. $[9,10]$ suggested that this bone remodeling was a consequence of biologic width formation around im- 


\section{Tooth}

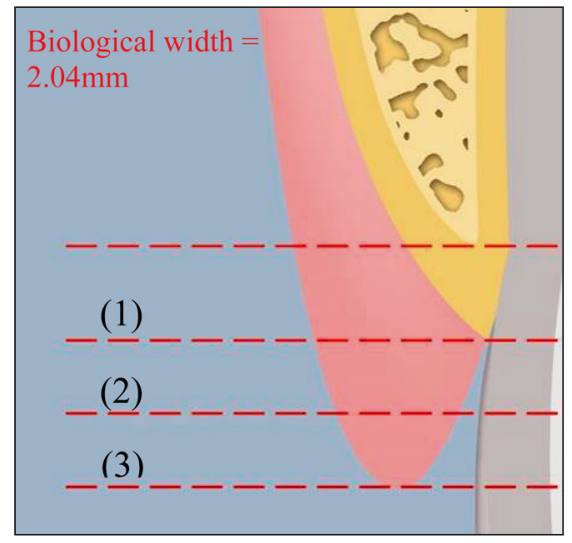

(1) Connective tissue attachment: $1.07 \mathrm{~mm}$

(2) Junctional epithelium: $0.97 \mathrm{~mm}$

(3) Sulcus: $0.69 \mathrm{~mm}$

\section{Implant}

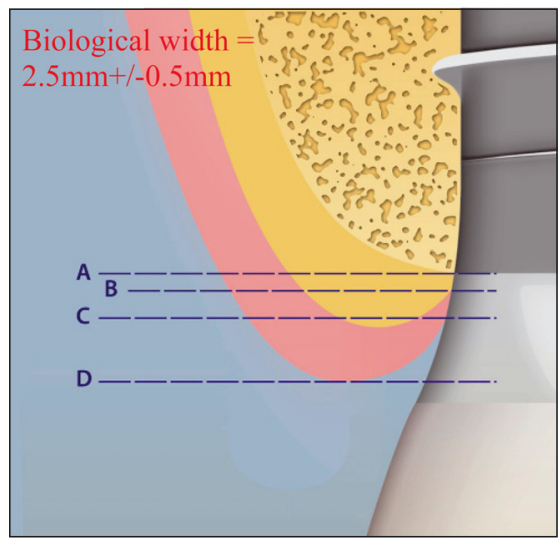

A-B : Connective tissue attachment: $1.5+/-0.5 \mathrm{~mm}$

B-C : Junctional epithelium: $1.5+/-0.5 \mathrm{~mm}$

C-D : Sulcus: $0.5-1 \mathrm{~mm}$

Fig. 1. The biological width of a tooth compared to that of an implant.

plants, which was physiologically determined, stable and dimensionally similar to that around teeth.

The formation of a biologic width can lead to a circumferential crater around the implant shoulder $[4,8,9]$. In areas of thin bone, the development of a crater may result in the loss of crestal bone height and gingival recession. This physiologic dimension, that was established early and maintained over time, appears to exist between the bone and the implant-crown interface around one-piece implants. It is consistent with the formation of a biologic width similar to that found around the natural dentition $[10,11]$ (Fig. 1). However, this biologic width is vulnerable to change. Bone loss may be observed in order to maintain the biologic width, particularly, as a response to various external factors.

Two other phenomena may participate in expected bone remodeling [11]. The first phenomenon determining bone loss is the location of the microgap (implant-abutment connection), in 2-stage implant surgeries. This also explains the $1.5 \mathrm{~mm}$ bone loss observed around submerged implants (when a microgap is created after abutment connection at the second-stage surgery) in the first year of function.

Secondly, the interface between the smooth and rough surface on an implant, is thought to play a major role. Bone loss is an adaptation to biomechanical influences, and implant placement depth determines the level at which it stabilizes $[8,10,11]$. Bone loss occurs up to that interface, and bone rarely stays on the machined surface. Thus, height of the smooth collar (e.g. $1.8 \mathrm{~mm}$ on Straumann ${ }^{\circledR}$ Esthetic implants) takes into consideration the notion of the biological width, in one-staged implant procedures. Having that in mind, any bone loss occurring further than that height (which happens to correspond to the smooth collar), could be considered as non-physiological bone loss. Based on these observations, this initial bone loss was considered as physiological remodeling; bone loss occurring beyond that point was hence regarded as pathological bone loss $[8,11]$.

This finding has been incorporated in the current study in an original way that enabled the investigators to consider the smooth-rough interface as the baseline bone level, up to which bone loss was considered as physiological.

In addition, external factors may participate in further bone remodeling, and hence bone loss. These will be detailed later.

\section{Radiographic methodology}

According to the literature, the majority of the radiographically measured bone loss occurred during the healing and remodeling periods, or within the first year of loading; very little bone loss occurred thereafter $[3,4,6,12]$. Radiographs are currently considered the gold standard in measuring bone level changes at interproximal implant sites (Fig. 2) and in evaluating the presence or absence of peri-implant radiolucencies [13-17].

Intra-oral radiography using the paralleling technique was recommended to evaluate minute bone changes [6]. The effects of the projection and the beam angle on the interpretation of non standardized films were reported by many authors [13-15].

\section{Annual peri-implant bone loss}

Several longitudinal studies consider that radiographic monitoring of bone level changes provides valuable insight into the longevity of oral implants [13-17] (Fig. 3). This indirect assessment is less invasive than the direct visualization of the inter-proximal bone through surgical access [15]. 


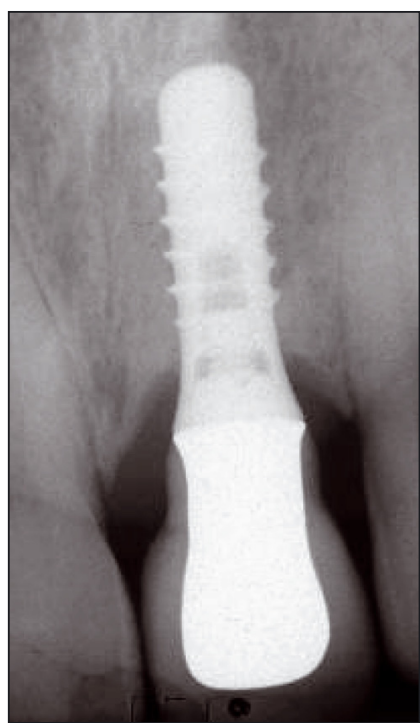

Fig. 2. Interproximal estimation of the bone levels on a peri-apical radiograph.

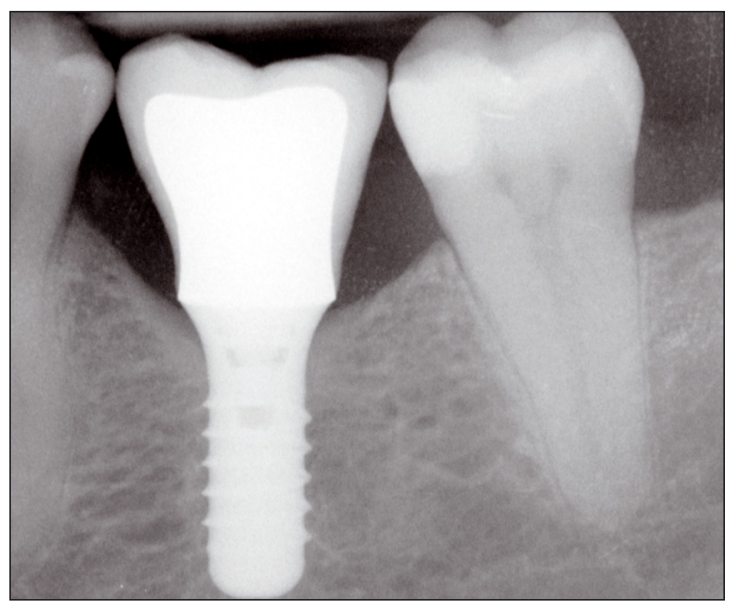

Fig. 3. A radiographic image ensures the visualization of the interproximal bone level.

Numerous long-term dental implant studies have utilized intraoral radiographs to assess marginal bone loss over time as a critical examination variable $[15,17,18]$. The consensus report of the 3rd European Workshop on Periodontolgy [19] assessed that a maximal bone loss of $2 \mathrm{~mm}$ between baseline (prosthesis in place) and the 5-year examination is acceptable. The risk of developing peri-implantitis and eventual implant loss has led the scientific community to search for accurate and reliable prognostic parameters.

The early longitudinal studies of Adell et al. in the 1980 s $[3,4]$ established that the majority of bone loss occurred during the healing and remodeling periods or within the first year of loading; very little bone loss occurs thereafter. Published data described a mean marginal bone loss of 0.4-0.5 mm during the first year post-implantation and 0.05-
$0.1 \mathrm{~mm}$ annually thereafter $[7,14]$. Similar observations were noted later by other research groups $[16,21,22]$, who defined the following measurements for the one stage ITI implants: $0.75 \mathrm{~mm}$ after the first year and less than $0.1 \mathrm{~mm}$ the following years. Another study determined that a mean crestal bone loss ranging from $0.9-1.6 \mathrm{~mm}$ in the first year after functional loading was acceptable [17]. A mean annual loss of $0.05-0.13 \mathrm{~mm}$ was reported in various studies with screwtype titanium implants $[11,14,21]$.

In their 5-year prospective study using standardized radiographs, Weber et al. [16] showed that the mean crestal bone loss for Straumann implants during the first year was approximately $0.6 \mathrm{~mm}$, followed by a yearly loss of $0.05 \mathrm{~mm}$. This study considered bone levels on the day of surgery as the baseline, which is uncommon in the dental implant literature to date. Most of the previous studies on machined surfaces measured bone loss in considering the point at which abutment connection was made as baseline (in the 2-stage technique). Hence they did not take into account bone remodeling that might have occurred previously. In contrast to the two- stage procedure implant system where osseointegration and marginal soft tissue adaptation occurs separately, theses healing events occur concomitantly usually within the first 3-4 months in 1-stage procedures, thus establishing a stabilized situation [11].

Certain studies suggest that implants with bone loss higher than $4 \mathrm{~mm}$ often showed a progressive loss of osseointegration, and possible implant loss in the subsequent years $[18,22]$. Probing depths of $5 \mathrm{~mm}$ are usually associated to a chronic inflammatory state. Thus, one major objective has been to develop therapies that aim to improve these critical peri-implant situations, to eliminate soft tissue pockets, and /or to regenerate bone [23].

Different values presented in the different studies were related to the variability in analysis methods and data selection. For instance, the Brånemark group excluded bone loss occurring during the first year; their results were expressed as mean values, and concerned a population with large interindividual deviation [24]. For Adell et al., the reported bone loss was $0.1 \mathrm{~mm}$ with high standard deviations [4]. Measurement errors were reported to be responsible for incorrect judgment of peri-implant bone level $[6,15,25]$. The level at which implants were placed, implant surface textures (machined, different rough surfaces), implant design, and one versus 2 -step surgical techniques were other factors that may explain the varying degrees of bone loss measured in the different studies [26-29]. Further studies should focus on the questions: does marginal bone height really decrease at a constant rate? What factors may affect such a decrease?

\section{Limitations of the radiological method}

Based on previously mentioned reports, radiographs with intraoral rectangular films were considered to ensure unbiased and reproducible results. The paralleling technique allows an optimum and reproducible quality of periapical radiographs $[30,33]$. However, any deviation from the correct 
vertical angle leads to errors in the assessments of the marginal bone height. According to the longitudinal study of Sewerin [34] on peri-implant bone loss, the distance between a reference point and the marginal bone level around implants could be assessed with a great accuracy by means of the long-cone paralleling technique, conventional or digitalised. The author measured, by evaluating bone height around both threaded and cylindrical implants on intra-oral radiographs, a mean inter-examiner difference of $0.09 \pm 0.16 \mathrm{~mm}$. Digital radiographs led to the same mean absolute difference $(0.18 \mathrm{~mm})$ as conventional intra-oral radiographic films $[6,35]$.

Differences in measurements may also be caused by the difficulty of placing the film intraorally. This occurs most often in the posterior maxilla because of the steep inclination of the palate, and in the anterior mandibular region. In the anterior mandible (especially in edentulous patients), many authors mentioned that the atrophy related elevation of the floor of the mouth, the pain and discomfort to the patient, all yield to difficulties in establishing good radiographs. Superimposition of the calcified structures of the jaw itself may also interfere with the measurement of the crestal bone level [34-36].

Spiekermann et al. [37] pointed out that with long observation periods; data taken from radiographs could be liable to a wide range of measurement errors that might hide the true bone level heights and resulting pocket depths.

The evaluation of periodontal or peri-implant marginal bone loss on dental radiographs implies the obvious disadvantage that only the mesial and distal bone levels could be distinguished [38-40]. However, this should not be of importance in crater-shaped peri-implant bone loss. The accurate value of bone loss tended to be underestimated on radiographs [39]. Moreover, variations in implant angulations in relation to the film plan as well as the direction of the radiographic beam influenced the image on the film. Small deviations from strict parallelism between implant and film plane were also able to significantly change bone height measurements $[38,41]$.

\section{Reliability of the radiological method}

As previously mentioned, a paralleling technique should be applied to minimize measurement errors. By using this technique, the film has to be positioned parallel to the axis of the implants and the film holder connected to the tube of a dental radiograph (Fig. 4). Correct vertical angle of projection is achieved when the threads on both sides are clearly identified [30].

Few studies dealt with accurate clinical and radiographic methods for detecting changes in the bone level. Radiographic assessment was compared to the histological method by Isidor [39]. In this study, clinical probing as well as radiographical and histological bone levels were assessed on machined surface implants placed in monkeys according to a 2-stage procedure. The author recommended the use of known hallmarks on the implant (smooth surface and threads) and

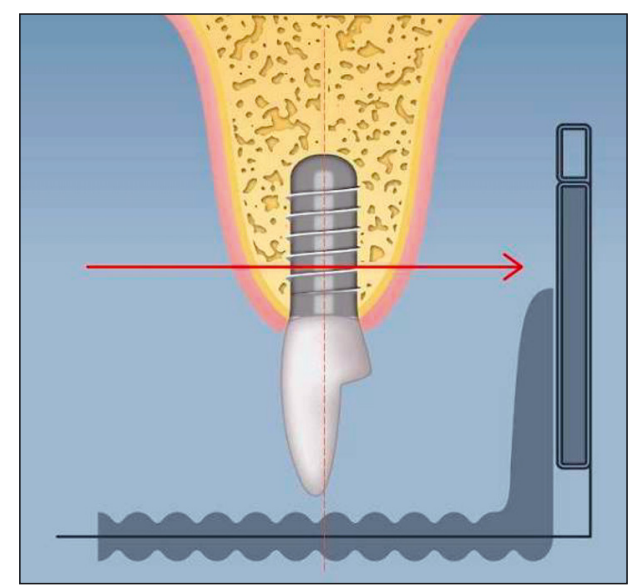

Fig. 4. The radiographic paralleling technique ensures correct estimation of the peri-implant bone level.

showed a high correlation between the radiographic measurements and the histological evaluation.

The relationship between probing level and radiographic bone level for screw-type implants was also assessed by Papelessi and Diamanti-Kipioti [30]. Furthermore, correlations between clinical probing and histological levels were also evaluated by an experimental study in the dog [40]. Hence, both radiographic interpretations of changes over time and measurements of attachment level changes are reliable in assessing the treatment outcome of inter-proximal intra-bony defects [24].

The evaluation of bone level changes over time requires high precision methods. This means that the obtained results should be similar when repeated by the same or different observers [25]. Variations within observers can be substantial when alveolar bone loss around teeth is assessed. However, when determining bone loss over time, some observers making several and independent readings are more precise than several readings by the same observer [25]. This principle was followed in the present study.

\section{Comparison of panoramic and periapical radiographs}

Panoramic radiography has been proposed to be an alternative method to measure bone loss [41]. Because of its standardized projection in the vertical plane, it suits well for vertical bone measurement. In addition, panoramic radiographs might be more appropriate in some cases than periapical radiographs because they offer an image of both jaws. They could also be used in patients with limited mouth opening [41]. Panoramic radiographs proved to be comparable to regular intraoral radiographs in detection of bone loss around implants in the anterior mandible, where periapical films were difficult to place [34].

However, the bidimensional view obtained with panoramic radiographs is blurred by the superimposition of the cervical column on the anterior region; therefore, the images seem 
magnified and distorted [33]. Some authors complained about its limited benefit owing to inferior image resolution and the inability to modify the radiographical beam angle. It was reported that the imaging accuracy of intraoral periapical radiography was 10 line pairs/mm (resolution $0.1 \mathrm{~mm}$ ), versus 5 line pairs $/ \mathrm{mm}$ (resolution $0.2 \mathrm{~mm}$ ) for panoramic radiographs [41]. Accordingly, an error of approximately $0.2 \mathrm{~mm}$ with a limited interobserver variation was reported for both intraoral periapical radiography and scanographic X-ray using the film technique, for in vitro peri-implant bone level evaluation $[6,42]$.

Nevertheless, the use of periapical radiographs to measure peri-implant bone levels has been well established. Periapical radiographs demonstrated to be an accurate method for crestal bone level evaluation around implants (within $0.2 \mathrm{~mm})[30,32]$.

In conclusion, periapical radiography was reported to be more successful than the panoramic one in the detection of small osseous destruction (4.7 x) [30]. Panoramic radiography underestimated the osseous destruction, whereas periapical radiography was relatively accurate for this assessment [33]. This was the case regardless of the location of the dental surfaces (jaw, tooth group, mesial or distal) and of the degree of osseous destruction. The two radiographic methods were more concordant in the assessment of osseous destruction in advanced periodontitis than in initial periodontitis [32].

Bone loss is thought to be underestimated in the range of 13 to $32 \%$ in orthopantomograms, $11-23 \%$ in bitewings, and $9-20 \%$ in periapical radiographs [33]. Taking into account such observations, patients with only panoramic follow-up radiographs for bone level analysis in the present study were not enrolled.

Digital radiographic images proved to offer higher image quality [35]. In specific cases, even panoramic digital images might therefore offer some specific potential for bone level evaluation. As digital intra-oral images showed the smallest absolute differences in intra- and inter-observer reproducibility, and since image resolution was somewhat higher when compared to conventional intra-oral radiography, they may be recommended for marginal bone level assessment around oral endosseous implants [42].

\section{Other predictors of bone loss and implant success}

Long cone periapical radiographs are used in most longitudinal studies to evaluate peri-implant radiolucencies $[6,7,13,15-18,31,44-51]$.

Several clinical studies indicated a maximum probe penetration of $3 \mathrm{~mm}$ for successful implants $[15,46,48,51]$. The two year longitudinal study of Brägger et al. [13] confirmed that the measurements of probing attachment level (PAT) along with radiographic parameters were good predictors of peri-implant bone level. The use of modified periodontal indices was suggested later [23,32]. The modified plaque and bleeding indices suggested by Mombelli and Lang [23] allowed a good evaluation of the state of the mucosa and oral hygiene. Additionally, several attempts to evaluate bone quality and density were investigated. For example, a radiographic index was created to measure bone apposition around implants after loading [6]. Dual photo absorptiometry was also used to quantify bone changes around implants [52]. Brägger et al. [53] established a sensitive method for periodontal and peri-implant bone assessment, using digital subtraction radiography and computer associated densitometric analysis. Low degrees of implant mobility could also be assessed using an electronic device (Periotest ${ }^{\circledR}$, Siemens, Bensheim, Germany). Mobility tests were not considered a valuable predictive method $[54,55]$. None of these methods were investigated in the current study.

\section{Factors influencing bone loss and implant failure}

Bone loss and biological failures were extensively studied on machined surface implants placed according to a 1-stage and 2-stage procedures $[1,3-5,54,55]$. Bone loss could be caused by any of the following reasons:

1. Surgical trauma due to elevation of the periosteum,

2. Mechanical overheating,

3. Excessive force exerted on the crestal bone at implant insertion,

4. Overloading due to traumatic occlusion, unfavorable jaw relationship and cantilever extensions,

5. Physiological residual ridge resorption,

6. Chronic connective tissue inflammation,

7. Peri-implantitis.

Bone loss within the first year of loading was also attributed to the biologic width formation [54], a process previously described. Implant failure was studied on machined implants as early as 1989 [55]. Two biological concepts have been proposed to explain pathological bone loss. The first is that periimplant bone loss, peri-implant radiolucency, mobility and eventually infection might be due to the loss of biomechanical equilibrium by excessive load. The authors hypothesized that a fibrous capsule, unable to contribute to functional loading of the bone-implant interface, replaces the highly specialized bone. The second is related to infection, it implies bacterial colonization and inflammation-related crestal bone resorption, and represents the most important etiological factor of pathological bone loss $[23,56]$.

\section{External factors that may further affect crestal bone level}

A literature search of possible parameters leading to crestal bone loss (CBL) showed that this may be affected by the following parameters: implant location, height of the smooth collar, implant diameter and length, implant surface texture, opposing occlusion, crown-to-implant ratio, type of suprastructure, as well as patient related factors such as periodontal disease, smoking, bruxism, and hygiene control $[1,18,19,22,55-65]$. 


\section{Aim of the study}

It was three folds:

1. To determine the five to six years success and survival rates of a population of 528 implants,

2. To evaluate radiographic bone changes around the implants,

3. To establish which factors may influence the degree of peri-implant bone change.

Unlike life-table analysis studies, all implants were evaluated at a minimum period of five years. All patients were treated and controlled in a private practice.

An original method was used to assess the pathological crestal bone loss (CBL) occurring during this period: the baseline bone level was considered to be located at the smoothrough implant interface, thus avoiding the need of reference radiographs. Bone loss was evaluated by only analyzing the radiographs taken at the 5 - to 6 -years control.

Different statistical tests were used to investigate the influence of various clinical parameters on CBL. Analyzed parameters were the following: implant location, implant diameter, implant length, implant collar height, implant surface texture type, implant prosthetic suprastructure type, implant vestibular bone lamella width (VBL) at surgery, implant distance to adjacent tooth/implant, opposing dentition type, patient smoking status.

The relevance of this study lies in the large number of implants and in the wide range of inclusive criteria for the patient selection. Furthermore, the absence of strict routine hygiene recalls as carried on in academic institutions can lead to realistic results that would apply in an every day dental practice

\section{Material and methods}

\section{Surgical and prosthetic procedures}

Between January 1995 and December 2000, 528 ITI dental implants (Straumann AG, Waldenburg, Switzerland) were inserted in 236 consecutive patients. These patients were treated in a private practice environment (Ardentis Clinique Dentaire SA, Vevey, Switzerland). They belonged to the same pool of patients investigated in previous studies $[64,66]$. Implants were placed by two surgeons (RN, MB) under clean but not sterile conditions as defined by Scharf \& Tarnow [67]. The patient population consisted of 145 females $(61.4 \%)$ and 91 males $(38.6 \%)$. Age at implant placement ranged from 18 to 89 years old; patients younger than 50 years old received $176(33.3 \%)$ implants, patients aged between 50 and 70 years received $278(52.6 \%)$ implants, while 74 (14.0\%) implants were placed in the elder patients. Before June 1999, $264(50 \%)$ titanium plasma sprayed (TPS) implants were inserted. After this date, 264 (50.0\%) sandblasted and acidetched (SLA) implants were placed.
In the mandible, implant length was assessed considering a $2-\mathrm{mm}$ security margin above the mandibular canal; therefore, standard insertion was performed when $10 \mathrm{~mm}$ of bone was available. In the maxilla, sinus perforation was not avoided; implant penetration in the sinus of 1 to $2 \mathrm{~mm}$ was tolerated. Standard insertion was performed when $5 \mathrm{~mm}$ of bone height was available. Esthetic Plus ${ }^{\circledR}$ implants (providing one additional millimetre for bone anchorage) were used when the esthetic situation required a deeper placement of the implant-crown junction in the sulcus [68] but not an enhanced anchoring length. Implant tilting to place a longer implant was not considered; $6 \mathrm{~mm}$ long implants were used only in conjunction with longer implants. Implant length (8, 10 or $12 \mathrm{~mm}$ ) was not taken into consideration to determine the number of implants, the type of prosthetic rehabilitation or its dimensions. Surgeons paid attention to place all roughsmooth junctions at the level of the mesial and distal crestal bone level or deeper. No implant was placed with the roughmachined limit above the crest at any proximal site.

The mean healing time for the TPS implants was 3.9 months in the mandible and 4.5 months in the maxilla. For the SLA implants, it was respectively 2.3 and 2.5 months. Prior to implantation, general health evaluation was performed and local clinical examinations were performed. No complementary biologic tests were requested. When required, implant treatment was decided after a benefit/risk analysis with the patient. A specific oral hygiene protocol was not followed, but the patients were given instructions about the importance of oral hygiene and the reduction/cessation of smoking habit, which was reinforced at every visit. A specific time period between tooth extraction and implant placement was not introduced: very few $(2.3 \%)$ implants were placed consecutively to tooth extraction, 34.9\% after 3-6 months, $15.9 \%$ after $6-12$ months and $47.0 \%$ after 1 year.

The patients' pool included bruxing patients (21.3\%), smokers $(26.3 \%)$ and medically compromised patients (20.1\%) like HIV+, controlled diabetes, malignant pathology other than in the cervico-facial area, heart disease or coagulation deficiency. Light or heavy smokers were included without distinction; smoking cessation was not requested either before or after surgery. Bruxers received one implant per rehabilitated unit; in case of multiple implant rehabilitation, these patients were encouraged to wear night-guards to avoid prosthetic complications. All surgical procedures were performed under antibiotic prophylaxis (Amoxi-basan ${ }^{\circledR}$, Schönenberger Pharma, Schönenwerd, Switzerland, $750 \mathrm{mg}, 3 x / \mathrm{d}$ during 6 days or Dalacin $C^{\circledR}$, Pfizer, Zürich, Switzerland, $300 \mathrm{mg}, 3 \mathrm{x} / \mathrm{d}$ during 5 days, in case of penicillin allergy) - The difference in the duration of the antibiotic treatment is related to the packaging system, in order to avoid for the patients to buy an extra pack in the case of Dalacin $C^{\circledR}$.

Treatment plans systematically included periodontal and carious status evaluations and, when necessary, disease management and maintenance prior to implant placement. All patients were instructed to attend at least a yearly routine hygienist session [69]. However, patients were not enrolled in this maintenance program. 


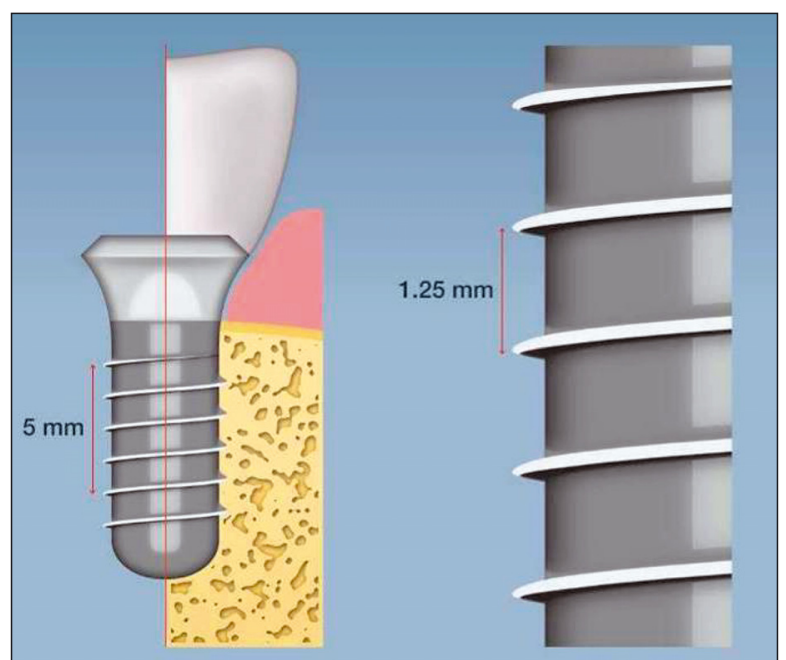

Fig. 5. Calibration was done knowing that the inter-thread distance is $1.25 \mathrm{~mm}$. The maximum number of threads visible on the $\mathrm{X}$-ray ( 5 in this example) was measured.

No exclusion criteria were applied in selecting this patient pool and hence all available patients were re-called for a five to six year postoperative $x$-ray of their implants.

\section{Patients enrolment}

All patients were contacted by phone or mail, in order to achieve the five-six year control including a periapical radiograph with the long cone paralleling technique. Those which had recent bitewing radiographs of the included implants already present in their charts were not required for further periapical ones.

\section{Data collection}

Of all examined intraoral radiographs, 65\% were conventional (non-digital) images. After November 2005, a digital system was installed in the clinic, and 35\% were digital images using the DBSWIN system ${ }^{\circledR}$ (Dürr Dental, BadenWürttemberg, Germany). The phosphorus plates this system has to offer allow it to be comparable to the conventional radiographic system (with silver halide grains) used earlier in the study. The DBSWIN system comprises an intraoral X-ray sensor VistaRay and the image plate systems VistaScan. It is a logistic system with extensive image processing and measurement tools.

Both methods used the paralleling long cone technique for the periapical radiographs. Conventional (non digital) films were then scanned in a digital format by a flatbed scanner (Epson Expression 1680 Pro, Wadenswil, Switzerland) with at least 600-1200 dpi resolution. All radiographs were then analyzed using image analysis software (Digora, Soredex, Helsinki, Finland), allowing a measurement precision of $0.01 \mathrm{~mm}$. To determine the magnification factor, an internal calibration was performed for each radiograph (Fig. 5). In

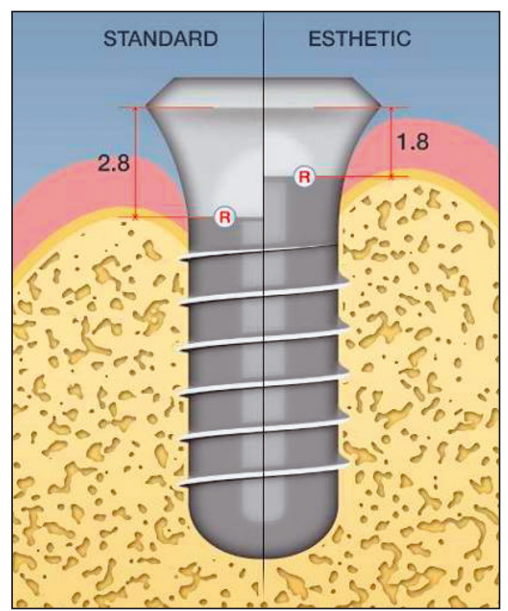

Fig. 6. Standard and esthetic implant collars; note the differences in the location of the $\mathrm{R}$ line.

order to improve the image analysis, image enhancement operations including sharpness, brightness, contrast and gamma adjustments were done when necessary.

\section{Measurement method}

Radiographic studies usually compare the bone loss reading between a reference radiograph taken after surgery or at prosthesis installation and at a given milestone [44-49]. In this study, the initial bone level was set according to histological studies carried out by Hermann et al. [8-10]. The authors implied that a physiologic bone loss occurs up to the level of the rough-smooth boundary of the implant. Having identified rough-smooth interface of the implant on the post-operative 5 -years radiographs, the need for a baseline radiograph was discarded.

When the bone level was found apical to that line, it was considered as a pathological bone loss. Bone appearing coronal to that line was considered as "supra-boundary bone" (for the definition see page 30). This does not necessarily mean new bone formation but simply identifies bone existing above the interface. The likely reason of the possible presence of bone above the interface is discussed later. Different factors were investigated for their effects on such bone changes.

It was therefore decided that the reference line $\mathrm{R}$ corresponding to the smooth-rough implant interface, is level with this physiological remodeling. This was dependent on smooth collar implant height (standard or esthetic implant) (Fig. 6).

Two different observers (HGD and SAN) were then subsequently asked to measure the distance parallel to the long implant axis between the $L$ line on the implant and the most apical part of the proximal marginal bone level. This measurement was carried out on both mesial and distal implant sides [15-17], on the 5-year postoperative radiographs. When unclear, the most apical bone-to-implant contact, corresponding to the worst case scenario was taken into account. 


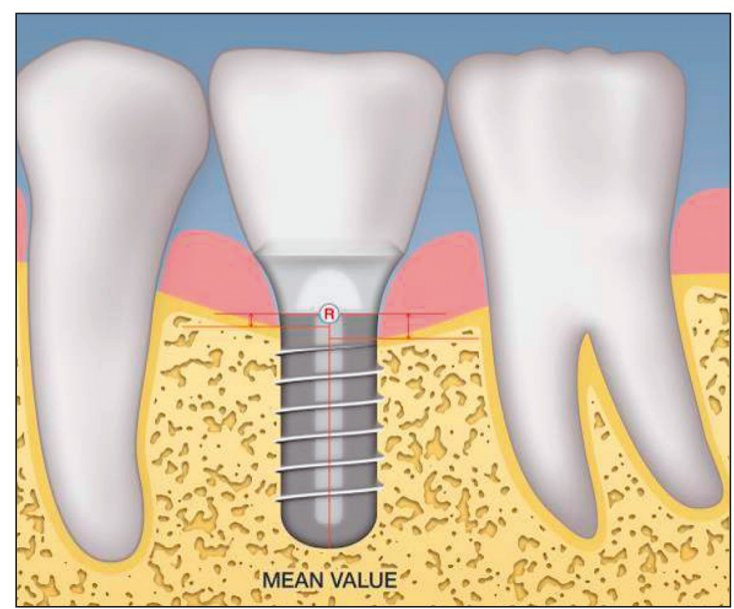

Fig. 7. Measurement method A.

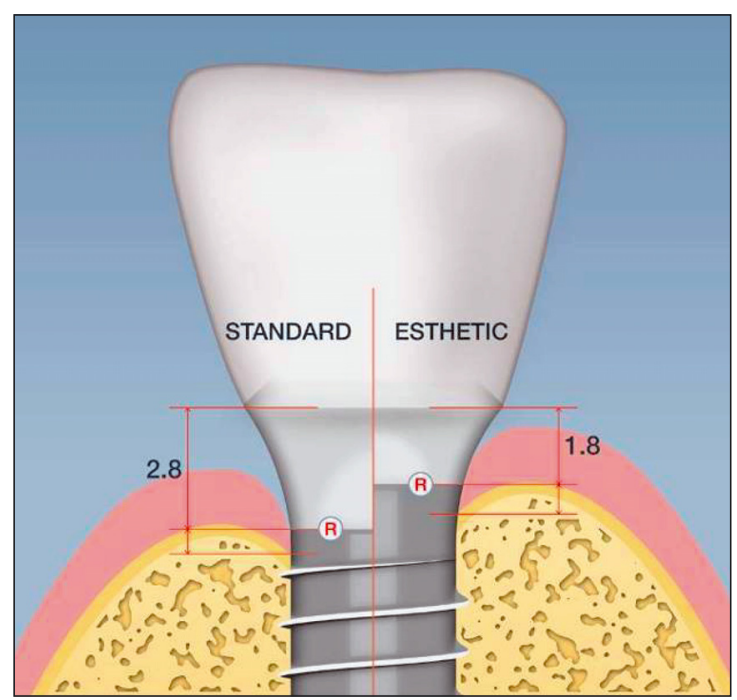

Fig. 8. Measurement method B.

The $\mathrm{R}$ line was determined by two different methods, depending on whether the apical part of the implant was visible (periapical radiographs) - method $\mathrm{A}$, or missing (bitewing radiographs) - method B:

1. Method A- Measures the implant length (given by the manufacturer) starting from the implant apex on the calibrated radiographic image taken with periapical radiographs (Fig. 7).

2. Method B-Measures the distance apical of the smooth implant collar, being $2.8 \mathrm{~mm}$ (standard implants) or $1.8 \mathrm{~mm}$ (for esthetic implants) as identified on the calibrated bitewing radiographs (Fig. 8 ).

Bone level was calculated for mesial and distal sites, and the mean was calculated. Sometimes, when only the mesial or distal side could be measured, the obtained value was considered combined. Crestal bone loss was abbreviated CBL.

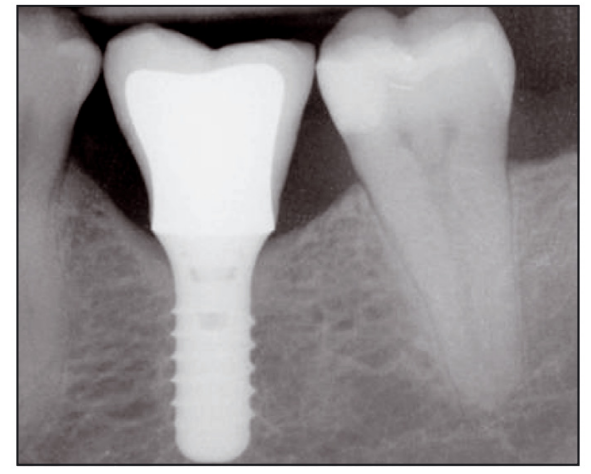

Fig. 9. Supra-boundary bone level.

Patients with only panoramic postoperative radiographs and who could not be contacted for intraoral periapical radiographs were not included in the radiographic analysis. Panoramic radiographs showed limited resolution, enlargement and distortion [33]. Radiographs were selected according to criteria established by both examiners (the two observers). This selection included unbent films, in addition to with a non distorted image, as well as films with correct orientation, contrast and brightness permitting mesial and/or distal identification of the most apical bone-to-implant contact

\section{"Supra-boundary bone"}

Unchanged bone level and bone above the smooth-rough interface on the radiographs was named "Supra-boundary bone" in the present study, this was considered as a "non bone loss" situation. Just because bone appears on the smooth surface radiographically, it is not an indication of actual bone formation, since it would primarily depend on the depth at which the implant was placed; in other words if bone had been on that surface at baseline (Fig. 9).

"Supra-boundary bone" was observed in some studies at approximately $30 \%$ of the Brånemark fixture surfaces between 1 and 3 years of follow-up $[4,29]$. This was interpreted as a physiological remodeling process in response to functional loading and adaptation, as well as a lack of standardization of the measurement technique.

\section{Investigated parameters}

The investigated parameters were selected due to their potential clinical influence on peri-implant bone remodeling. They are as follows:

1. Implant jaw location (maxilla/mandible),

2. Height of the implant smooth collar (standard/esthetic),

3. Implant surface topography (TPS/SLA),

4. Opposing dentition,

5. Smoking status,

6. Location of implant (anterior/posterior), 


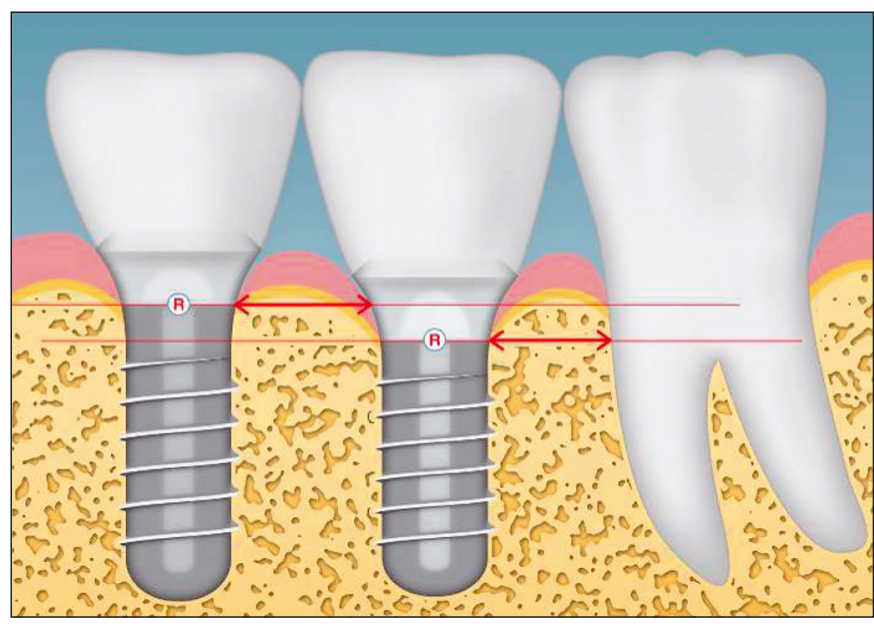

Fig. 10. Implant-tooth and implant-implant distance measurement.

7. Implant length,

8. Implant diameter,

9. Implant prosthetic suprastructure,

10. Implant vestibular bone lamella width (VBL) at surgery: VBL $<1 \mathrm{~mm}$ or $\mathrm{VBL} \geqslant 1 \mathrm{~mm}$,

11. Implant distance to adjacent tooth/implant. This was measured by drawing a straight line from the $(R)$ line to the adjacent tooth or implant (Fig. 10).

\section{Criteria for determining interpretable radiographs}

Strict inclusion criteria were used to determine the bone level changes for the obtained radiographs. All bent and unclear radiographs were excluded from the analysis; however, they were included for success and survival rate evaluations. Radiographs had to fulfill the following criteria to be considered -after calibration- for peri-implant bone level measurements:

1. An equal distance $(1.25 \mathrm{~mm})$ between all the threads of the implant along the entire implant surface,

2. An equal distance of the diameter of the implant (thread to thread) at two different random spots along the implant body,

3. The diameter of the collar and the implant length corresponded to the values given by the manufacturer; i.e. the $\mathrm{R}$ line had to present the same location when determined from the collar (at a distance of 2.8 or $1.8 \mathrm{~mm}$ ) or from the tip of the implant (corresponding to the value of the implant length).

If the second trial of X-ray capture didn't also yield the required quality, the radiographs were eliminated from the study. When an observer could not confidently identify the implant collar and the most apical bone-to-implant contact, radiographic measurements were not included. Bitewing radiographs were also considered for bone level evaluation, since bone level changes in the follow-up period always began around the neck of the implant [34].

\section{Survival and success rates' evaluation}

Survival rate was defined as the proportion of implants in place and in function $[3,7,13,18,65,70]$ at the $5-6$ years reevaluation. Success rate was considered as the proportion of implants showing no mobility, no peri-implant radiolucency, no active or recurrent peri-implantitis $[5,55,65]$ and no radiological CBL $>3 \mathrm{~mm}$.

\section{Statistical analysis}

The coefficient of reliability was calculated in order to determine the accuracy of measurements between the two observers. Descriptive tables were used to calculate the mean $\mathrm{CBL}$ according to the different parameters. The difference between two similar variables i.e. TPS versus SLA or smokers versus non-smokers was evaluated using the Student T-Test $(p<0.001)$.

ANOVA regression analysis was used to analyze the influence of the variables on CBL or "supra-boundary bone". These variables were classified in groups depending on values of CBL and presence of "supra-boundary bone" 1) CBL $>3 \mathrm{~mm}$, 2) $2 \mathrm{~mm}<C B L \leqslant 3 \mathrm{~mm}$, 3) $1 \mathrm{~mm}<C B L \leqslant 2 \mathrm{~mm}, 4)$ $\mathrm{CBL} \leqslant 1 \mathrm{~mm}, 5)$ "supra-boundary bone" $(p<0.05)$ (Fig. 10).

The Pearson Chi-Square Test was also used to evaluate the correlation between the different parameters and bone change.

Finally, the influence of various combined factors was evaluated in regard to their influence on CBL. This was investigated with the ANOVA Univariate Analysis Test $(p<0.05)$.

\section{Results}

\section{Drop-outs and final patients population}

Sixty-two participants (26.3\%) dropped out of this study, corresponding to $117(22.2 \%)$ implants. The reasons for dropouts included deceased 7 patients (15 implants), 51 patients out of reach (92 implants), 1 patient delaying implant loading because of financial problems ( 2 implants), 2 patients refusing irradiation (6 implants), 1 patient unwilling to attend (2 implants).

At the end of the 5-6 year study period, three implants in two patients failed, bringing the survival rate down to $99.2 \%$.

The radiographs of 15 patients (22 implants) did not correspond to the above established criteria for bone level evaluation: $57 \%$ of the 22 implants were located in the posterior maxilla and $43 \%$ in the anterior mandible (from canine to canine). Nevertheless, these radiographs were included in the determination of the success and survival rates. The final implant population sample reached 411 implants $(77.8 \%$ of the initial population) in 174 patients for survival rate evaluation, and 386 implants (73.1\% of the initial population) for bone level and hence success evaluations. 
Table 1. Inter-observer coefficient of reliability.

\begin{tabular}{|c|c|c|c|c|c|c|c|c|c|}
\hline \multirow[b]{2}{*}{$\begin{array}{l}\text { Bone } \\
\text { Loss }\end{array}$} & \multirow[b]{2}{*}{$n$} & \multicolumn{2}{|c|}{ Observer 1} & \multicolumn{2}{|c|}{ Observer 2} & \multicolumn{3}{|c|}{$\begin{array}{c}95 \% \text { confidence interval } \\
\text { of the difference }\end{array}$} & \multirow[b]{2}{*}{$\begin{array}{l}\text { Coefficient } \\
\text { of reliability }\end{array}$} \\
\hline & & $\begin{array}{l}\text { mean } \\
\text { value } \\
(\mathrm{mm})\end{array}$ & $\begin{array}{c}\text { standard } \\
\text { deviation } \\
(\mathrm{mm})\end{array}$ & $\begin{array}{l}\text { mean } \\
\text { value } \\
(\mathrm{mm})\end{array}$ & $\begin{array}{c}\text { standard } \\
\text { deviation } \\
(\mathrm{mm})\end{array}$ & $\begin{array}{c}\text { lower } \\
\text { bound } \\
(\mathrm{mm})\end{array}$ & $\begin{array}{l}\text { upper } \\
\text { bound } \\
(\mathrm{mm})\end{array}$ & $p$-value & \\
\hline Mesial & 385 & 1.09 & 0.00 & 1.09 & 0.54 & -0.06 & 0.06 & 0.93 & 0.87 \\
\hline Distal & 386 & 1.20 & 0.04 & 1.17 & 0.57 & -0.02 & 0.09 & 0.20 & 0.88 \\
\hline
\end{tabular}

The final population included $49.7 \%$ TPS-surfaced implants and $50.3 \%$ SLA-surfaced implants. Of these, $27.5 \%$ were placed in the anterior segment and $72.5 \%$ in the posterior region. Implants placed in the maxilla comprised $39.9 \%$ of the total implants, while $60.1 \%$ were placed in the mandible. The majority of the population had a natural/fixed opposing dentition $(76.4 \%), 17.6 \%$ had a removable opposing dentition and $4.4 \%$ had a mixed opposing dentition. Most implants $(93.5 \%)$ were solid screws $(2.0 \%$ with a $3.3 \mathrm{~mm}$ diameter collar, $92.0 \%$ with a $4.8 \mathrm{~mm}$ and $6 \%$ with a $6.5 \mathrm{~mm}$ ) and $6.5 \%$ were hollow screws. $17 \%$ presented an esthetic collar and $83.0 \%$ a standard collar. Restorations were fixed $(79.0 \%)$ and removable (21.0\%). $12.4 \%$ of the removable suprastructure had a clip attachment design and $7.5 \%$ a bar attachment. $19.2 \%$ of the implants were placed in smoking patients and $80.8 \%$ in non-smokers. Rough-surface implants length distribution was the following: $1.0 \%: 6 \mathrm{~mm}, 21.5 \%: 8 \mathrm{~mm}, 1.6 \%$ : $9 \mathrm{~mm}$ (Esthetic Plus ${ }^{\circledR} 8 \mathrm{~mm}$ ), 39.1\%: $10 \mathrm{~mm}, 10.9 \%: 11 \mathrm{~mm}$ (Esthetic Plus ${ }^{\circledR} 10 \mathrm{~mm}$ ), 24.4\%: $12 \mathrm{~mm}, 1.6 \%: 13 \mathrm{~mm}$ (Esthetic Plus ${ }^{\circledR} 12 \mathrm{~mm}$ ). At surgery, by the end of the drilling sequence and prior to implant placement, $72.8 \%$ of the implants presented a VBL higher than $1 \mathrm{~mm}$ and $27.2 \%$ less than $1 \mathrm{~mm}$. Of the implants that displayed a VBL less than $1 \mathrm{~mm}$, $27.6 \%$ were placed with a simultaneous lateral augmentation technique: xenograft (Bio-Oss ${ }^{\circledR}$, Geistlich, Switzerland) and a resorbable membrane (Bio-Gide ${ }^{\circledR}$, Geistlich, Switzerland). $72.4 \%$ of those with VBL less than $1 \mathrm{~mm}$ had no augmentation technique.

\section{Examined radiographs}

$91.3 \%$ of the final radiographs were obtained from periapical radiographs and the rest $(8.7 \%)$ were obtained from bitewings. Both types presented high sensitivities for periimplant bone loss measurements [30]. As mentioned previously, the bitewing radiographs that were in the patient chart before as part of a routine control imaging were used in the study in order to prevent further irradiation. This explains the small percentage of this type of radiographs.

\section{Survival and success rates}

Three failures in two patients were recorded. They were divided into early failure ( 1 implant, $0.2 \%$ ) before loading and late failures (2 implants, $0.4 \%$ ) after loading. The early failure was related to infection whereas late failures were related to implant overloading and mobility. Interestingly, all failures occurred during the first year.

The overall survival rate at the 5-6 year control was $99.2 \%$. However, $7 \%$ of the implants showed radiological bone loss greater than $3 \mathrm{~mm}$, decreasing the success rate to $93 \%$.

Peri-implantitis, utilizing both clinical and radiological evaluation, was observed on six implants $(1.6 \%)$ in four patients. Five occurred in the mandible whereas four in the posterior area. Surgical procedures were not undertaken to treat peri-implantitis. They were treated locally according to the Cumulative Interceptive Supportive Therapy (CIST) protocol [23]. In addition, a strict hygiene protocol was recommended and more frequent recall appointments (every 4 months instead of the recommended annual recall). The treated implants were followed up over subsequent years, and showed no signs of recurrent peri-implantitis. No implants manifested signs of mobility, and subjects did not complain of persistent pain, foreign body sensation and/or dysthesia.

\section{Statistical analysis}

Several tests were included in the statistical analysis using the data analysis program (SPSS).

The coefficient of reliability showed no significant difference $(p>0.05)$ when comparing the measurements taken by the two observers (Table 1 ). Therefore, a combined mean value of the two measurements was used.

Mean bone loss

Mean bone loss (mean mesial and distal heights) measured by both observers was $1.16 \mathrm{~mm}$ (range $0-5.41 \mathrm{~mm}$, $\mathrm{SD} \pm 1.03 \mathrm{~mm})$.

\section{Effect of different factors on mean CBL}

Student t-test showed the following mean CBLs for the different factors investigated (Tables 2-13).

\section{ANOVA regression analysis}

According to the ANOVA regression analysis, and in accordance with the Student t-test done previously, four factors 
Table 2. Surface topography effect on mean CBL. SLA: sand blasted large grit acid etched surface, TPS: titanium plasma-sprayed surface.

\begin{tabular}{|c|c|c|c|}
\hline Surface & Mean CBL $(\mathrm{mm})^{*}$ & Standard deviation (mm) & $n$ \\
\hline SLA & 0.86 & 0.83 & 192 \\
\hline TPS & 1.24 & 1.17 & 194 \\
\hline
\end{tabular}

*Statistically significant difference between SLA and TPS surfaces and mean CBL $(p<0.001)$.

Table 3. Effect of different implant designs on mean CBL. HS: hollow screw implant. SS: small screw implant, S: standard implant, SE: standard implant with esthetic collar, WN: wide neck implant, NN: narrow neck implant, L: large body implants.

\begin{tabular}{|c|c|c|c|}
\hline Design & Mean CBL $(\mathrm{mm})^{*}$ & Standard deviation (mm) & $n$ \\
\hline HS & 1.22 & 1.31 & 24 \\
\hline SS & 1.58 & 1.20 & 9 \\
\hline S & 1.04 & 1.00 & 246 \\
\hline SE & 1.19 & 1.13 & 65 \\
\hline WN & 0.59 & 0.63 & 25 \\
\hline NN & 0.89 & 0.76 & 8 \\
\hline L & 1.05 & 0.96 & 9 \\
\hline
\end{tabular}

* No statistically significant difference found between various implant designs on mean CBL $(p=0.946)$.

Table 4. Effect of arch location on mean CBL. The difference was significant with $P<0.001$.

\begin{tabular}{|c|c|c|}
\hline Arch location* $^{*}$ & Mean CBL (mm) & $n$ \\
\hline Posterior & 0.95 & 280 \\
\hline Anterior & 1.31 & 106 \\
\hline
\end{tabular}

* Statistically significant difference between anterior or posterior position and mean CBL $(p<0.001)$.

Table 5. Effect of implant diameter on mean CBL.

\begin{tabular}{|c|c|c|c|}
\hline $\begin{array}{c}\text { Implant diameter } \\
(\mathrm{mm})^{*}\end{array}$ & $\begin{array}{c}\text { Mean CBL } \\
(\mathrm{mm})\end{array}$ & $\begin{array}{c}\text { Standard deviation } \\
(\mathrm{mm})\end{array}$ & $n$ \\
\hline 4.1 & 1.09 & 1.05 & 356 \\
\hline 3.3 & 0.89 & 0.76 & 7 \\
\hline 4.8 & 0.52 & 0.55 & 23 \\
\hline
\end{tabular}

* No statistically significant difference found between implant diameter and mean CBL $(p=0.138)$.

Table 6. Effect of height of the smooth collar on mean CBL.

\begin{tabular}{|c|c|c|c|}
\hline $\begin{array}{c}\text { Height of the } \\
\text { smooth collar }\end{array}$ & $\begin{array}{c}\text { Mean CBL } \\
(\mathrm{mm})^{*}\end{array}$ & $\begin{array}{c}\text { Standard deviation } \\
(\mathrm{mm})\end{array}$ & $n$ \\
\hline Esthetic $(1.8 \mathrm{~mm})$ & 1.15 & 1.13 & 77 \\
\hline Standard $(2.8 \mathrm{~mm})$ & 1.03 & 1.00 & 319 \\
\hline
\end{tabular}

${ }^{*}$ No statistically significant difference found between height of smooth collar and mean CBL $(p=0.435)$.

Table 7. Effect of jaw location on mean CBL.

\begin{tabular}{|c|c|c|c|}
\hline Jaw location & Mean CBL (mm)* & $\begin{array}{c}\text { Standard deviation } \\
(\mathrm{mm})\end{array}$ & $n$ \\
\hline Maxilla & 1.08 & 0.99 & 155 \\
\hline Mandible & 1.03 & 1.06 & 231 \\
\hline
\end{tabular}

* No statistically significant difference found between jaw location and mean CBL $(p=0.170)$. 
Table 8. Effect of opposing dentition on mean CBL.

\begin{tabular}{|c|c|c|c|}
\hline Opposing dentition & $\begin{array}{c}\text { Mean CBL } \\
(\mathrm{mm})^{*}\end{array}$ & $\begin{array}{c}\text { Standard deviation } \\
(\mathrm{mm})\end{array}$ & $n$ \\
\hline Natural/Fix & 1.00 & 1.03 & 296 \\
\hline Removable & 1.06 & 0.96 & 69 \\
\hline Mixed & 1.56 & 1.11 & 21 \\
\hline
\end{tabular}

* No statistically significant difference found between opposing dentition type and mean CBL $(p=0.931)$.

Table 9. Effect of suprastructure on mean CBL.

\begin{tabular}{|c|c|c|c|}
\hline Suprastructure & $\begin{array}{c}\text { Mean CBL } \\
(\mathrm{mm})^{*}\end{array}$ & $\begin{array}{c}\text { Standard deviation } \\
(\mathrm{mm})\end{array}$ & $n$ \\
\hline Fixed & 0.99 & 1.01 & 305 \\
\hline Removable & 1.28 & 1.03 & 81 \\
\hline
\end{tabular}

*No statistically significant difference between suprastructure type and mean CBL $(p=0.7)$.

Table 10. Effect of smoking status on mean CBL.

\begin{tabular}{|c|c|c|c|}
\hline Smoking status & $\begin{array}{c}\text { Mean CBL } \\
(\mathrm{mm})^{*}\end{array}$ & $\begin{array}{c}\text { Standard deviation } \\
(\mathrm{mm})\end{array}$ & $n$ \\
\hline Non-smoker & 0.97 & 0.95 & 309 \\
\hline Smoker & 1.36 & 1.27 & 77 \\
\hline
\end{tabular}

* A statistically significant difference was found between smoking status and mean CBL $(p<0.001)$. Smokers demonstrated significantly more mean $\mathrm{CBL}$.

Table 11. Effect of implant length on mean CBL.

\begin{tabular}{|c|c|c|c|}
\hline Implant length & $\begin{array}{c}\text { Mean CBL } \\
(\mathrm{mm})^{*}\end{array}$ & $\begin{array}{c}\text { Standard deviation } \\
(\mathrm{mm})\end{array}$ & $n$ \\
\hline $6 \mathrm{~mm}$ & 1.33 & 0.76 & 4 \\
\hline $8 \mathrm{~mm}$ & 0.88 & 0.92 & 83 \\
\hline $9 \mathrm{~mm}$ & 0.86 & 0.96 & 6 \\
\hline $10 \mathrm{~mm}$ & 1.14 & 1.17 & 151 \\
\hline $11 \mathrm{~mm}$ & 1.09 & 1.00 & 42 \\
\hline $12 \mathrm{~mm}$ & 1.03 & 0.91 & 94 \\
\hline $13 \mathrm{~mm}$ & 1.30 & 0.83 & 6 \\
\hline
\end{tabular}

* No statistically significant difference was found when evaluating implant length in regard to mean CBL $(p=0.901)$.

Table 12. Effect of VBL width on mean CBL.

\begin{tabular}{|c|c|c|c|}
\hline VBL & $\begin{array}{c}\text { Mean CBL } \\
(\mathrm{mm})^{*}\end{array}$ & $\begin{array}{c}\text { Standard deviation } \\
(\mathrm{mm})\end{array}$ & $n$ \\
\hline$>1 \mathrm{~mm}$ & 0.96 & 0.91 & 281 \\
\hline$<1 \mathrm{~mm}$ & 1.29 & 1.28 & 105 \\
\hline
\end{tabular}

* A statistically significant difference was found when evaluating VBL effect on mean CBL $(p<0.001)$. Increased mean CBL was observed when $<1 \mathrm{~mm}$ VBL remained.

Table 13. Effect of adjacent tooth/ implant distance on mean CBL.

\begin{tabular}{|c|c|c|c|}
\hline $\begin{array}{c}\text { Distance to adjacent } \\
\text { tooth/implant }\end{array}$ & $\begin{array}{c}\text { Mean CBL } \\
(\mathrm{mm})^{*}\end{array}$ & $\begin{array}{c}\text { Standard deviation } \\
(\mathrm{mm})\end{array}$ & $n$ \\
\hline $1-2 \mathrm{~mm}$ & 1.02 & 0.94 & 33 \\
\hline $2-3 \mathrm{~mm}$ & 1.11 & 1.15 & 151 \\
\hline $3-4 \mathrm{~mm}$ & 1.05 & 1.25 & 66 \\
\hline$>4 \mathrm{~mm}$ & 1.04 & 0.93 & 136 \\
\hline
\end{tabular}

\footnotetext{
* No statistically significant difference found when evaluating distance between adjacent tooth implant and mean CBL $(p=0.435)$.
} 
Table 14. Evaluation of implant surface (TPS versus SLA) and arch location (anterior versus posterior) in relation to mean crestal bone loss.

\begin{tabular}{|c|c|c|c|c|c|c|c|}
\hline Surface* & $\begin{array}{c}\text { Arch } \\
\text { location* }\end{array}$ & $\begin{array}{l}\text { Mean bone } \\
\text { loss }(\mathrm{mm})\end{array}$ & $\begin{array}{c}\text { Standard } \\
\text { error } \\
(\mathrm{mm})\end{array}$ & $\begin{array}{c}\text { Lower } \\
\text { bound } \\
(\mathrm{mm})\end{array}$ & $\begin{array}{c}95 \% \\
\text { Confidence } \\
\text { interval } \\
\text { Upper } \\
\text { bound } \\
(\mathrm{mm})\end{array}$ & $p$-value & $n$ \\
\hline \multirow{2}{*}{ SLA } & posterior & 1.00 & 0.10 & 0.79 & 1.21 & NS & 133 \\
\hline & anterior & 1.43 & 0.26 & 0.92 & 1.95 & NS & 59 \\
\hline \multirow{2}{*}{ TPS } & posterior & 1.58 & 0.13 & 1.32 & 1.84 & NS & 149 \\
\hline & anterior & 1.63 & 0.20 & 1.24 & 2.03 & $<0.05$ & 47 \\
\hline
\end{tabular}

* A statistically significant mean bone loss occurred for TPS surfaced implants located in the anterior arch $(p<0.05)$.

Table 15. Combination of implant surface (TPS versus SLA) and smoking status in assessing mean bone loss. Highest bone loss occurred for TPS-surfaced implants placed in smoking subjects.

\begin{tabular}{|c|c|c|c|c|c|c|c|}
\hline Surface* & $\begin{array}{l}\text { Smoking } \\
\text { status* }\end{array}$ & $\begin{array}{l}\text { Mean bone } \\
\text { loss (mm) }\end{array}$ & $\begin{array}{c}\text { Standard } \\
\text { error } \\
(\mathrm{mm})\end{array}$ & $\begin{array}{c}\text { lower } \\
\text { bound } \\
(\mathrm{mm})\end{array}$ & $\begin{array}{c}\text { upper } \\
\text { bound } \\
(\mathrm{mm})\end{array}$ & $p$-value & $n$ \\
\hline \multirow{2}{*}{ SLA } & non-smoking & 0.82 & 0.09 & 0.63 & 1.02 & NS & 146 \\
\hline & smoking & 1.40 & 0.28 & 1.06 & 2.15 & NS & 46 \\
\hline \multirow{2}{*}{ TPS } & non-smoking & 1.40 & 0.09 & 1.22 & 1.59 & NS & 163 \\
\hline & smoking & 1.61 & 0.21 & 1.41 & 2.21 & $<0.05$ & 31 \\
\hline
\end{tabular}

* A statistically significant mean bone loss occurred in smoker subjects on TPS surfaced implants located in the anterior arch $(p<0.05)$.

Table 16. Evaluation of arch location (anterior versus posterior) and smoking status in relation to mean bone loss.

\begin{tabular}{|c|c|c|c|c|c|c|c|}
\hline \multirow{2}{*}{$\begin{array}{c}\text { Smoking } \\
\text { status* }\end{array}$} & $\begin{array}{c}\text { Arch } \\
\text { location* }\end{array}$ & $\begin{array}{c}\text { Mean } \\
\text { bone loss } \\
(\mathrm{mm})\end{array}$ & $\begin{array}{c}\text { Standard } \\
\text { error } \\
(\mathrm{mm})\end{array}$ & $\begin{array}{c}\text { 95\% confidence } \\
\text { interval } \\
\text { lower } \\
\text { bound } \\
(\mathrm{mm})\end{array}$ & $\begin{array}{c}\text { upper } \\
\text { bound } \\
(\mathrm{mm})\end{array}$ & $p$-value & $n$ \\
\hline \multirow{2}{*}{ Non-smoking } & posterior & 1.03 & 0.24 & 0.54 & 1.52 & $\mathrm{NS}$ & 229 \\
\cline { 2 - 9 } & anterior & 1.25 & 0.18 & 0.90 & 1.59 & $\mathrm{NS}$ & 80 \\
\hline \multirow{2}{*}{ Smoking } & posterior & 1.19 & 0.65 & -0.10 & 2.48 & $\mathrm{NS}$ & 51 \\
\cline { 2 - 9 } & anterior & 1.68 & 0.56 & 0.57 & 2.79 & $<0.05$ & 26 \\
\hline
\end{tabular}

* A statistically significant mean bone loss occurred for implants located in the anterior arch and placed in smoking subjects $(p<0.05)$.

showed statistically significant results when investigating their influence on peri-implant bone change $(p<0.05)$ (Tables 14-25). These factors were:

1. Implant surface topography (TPS $>$ SLA),

2. Smoking status (smoking $>$ non-smoking),

3. Anterior versus posterior location (anterior $>$ posterior),

4. Width of the vestibular bone lamella $(\mathrm{VBL}<1 \mathrm{~mm}$ showed greater bone loss than VBL $>1 \mathrm{~mm}$ ).

Multiple regression analysis used to evaluate the significance of the influence on the mean bone loss of the following factors: implant surface, smoking status, anterior-posterior location and vestibular bone lamella width.
Multiple regression analysis of mean bone loss in relation to: (a) implant surface, (b) smoking status, (c) anteriorposterior location and (d) vestibular bone width.

Independent variables: surface (SLA, TPS) + smoking status (non-smoking, smoking) + arch location + vestibular bone.

$b_{0}=$ constant, $b_{1}, b_{2}, b_{3}, b_{4}=$ regression coefficients, $R=$ correlation coefficient, $R^{2}=$ percentage of explained variance.

Multiple regression analysis

$Y=-35.762+b_{1}$ surface texture $+b_{2}$ tobacco $+b_{3}$ arch location $+b_{4}$ vestibular bone width.

Independent variables: surface texture, tobacco, arch location, and vestibular bone width on bone loss. 
Table 17. Evaluation of arch location (anterior versus posterior), smoking status and implant surface (TPS versus SLA) in relation to mean bone loss.

\begin{tabular}{|c|c|c|c|c|c|c|c|c|}
\hline Surface* & $\begin{array}{c}\text { Arch } \\
\text { location* }\end{array}$ & $\begin{array}{l}\text { Smoking } \\
\text { status* }\end{array}$ & $\begin{array}{c}\text { Mean } \\
\text { bone loss } \\
(\mathrm{mm})\end{array}$ & $\begin{array}{c}\text { Standard } \\
\text { error } \\
(\mathrm{mm})\end{array}$ & $\begin{array}{c}\text { lower } \\
\text { bound } \\
(\mathrm{mm})\end{array}$ & $\begin{array}{c}\text { upper } \\
\text { bound } \\
(\mathrm{mm})\end{array}$ & $p$-value & $n$ \\
\hline \multirow{4}{*}{ SLA } & \multirow{2}{*}{ posterior } & Non-smoking & 0.69 & 0.11 & 0.48 & 0.89 & NS & 102 \\
\hline & & Smoking & 1.31 & 0.19 & 0.94 & 1.69 & NS & 31 \\
\hline & \multirow{2}{*}{ anterior } & Non-smoking & 0.96 & 0.17 & 0.63 & 1.29 & NS & 44 \\
\hline & & Smoking & 1.17 & 0.36 & 1.59 & 3.02 & NS & 15 \\
\hline \multirow{4}{*}{ TPS } & \multirow{2}{*}{ posterior } & Non-smoking & 1.11 & 0.09 & 0.92 & 1.30 & NS & 127 \\
\hline & & Smoking & 2.04 & 0.25 & 1.55 & 2.53 & NS & 20 \\
\hline & \multirow{2}{*}{ anterior } & Non-smoking & 1.69 & 0.16 & 1.38 & 2.01 & NS & 36 \\
\hline & & Smoking & 2.31 & 0.50 & 0.19 & 2.16 & $<0.05$ & 11 \\
\hline
\end{tabular}

* A statistically significant mean bone loss occurred when a combination TPS-surfaced implants were placed in a smoking patient in the anterior arch $(p<0.05)$

Table 18. Evaluation of implant surface (TPS versus SLA) and width of vestibular bone lamella (VBL $<1 \mathrm{~mm}$ or VBL $>1 \mathrm{~mm}$ ) in relation to mean bone loss.

\begin{tabular}{|c|c|c|c|c|c|c|c|}
\hline \multirow{2}{*}{ Surface* } & \multirow{2}{*}{ VBL* } & \multirow[b]{2}{*}{$\begin{array}{l}\text { Mean bone } \\
\text { loss }(\mathrm{mm})\end{array}$} & \multirow[b]{2}{*}{$\begin{array}{l}\text { Standard } \\
\text { error }(\mathrm{mm})\end{array}$} & \multicolumn{2}{|c|}{$\begin{array}{l}95 \% \text { confidence } \\
\text { interval }\end{array}$} & \multirow[b]{2}{*}{$p$-value } & \multirow[b]{2}{*}{$n$} \\
\hline & & & & $\begin{array}{l}\text { lower } \\
\text { bound } \\
\text { (mm) }\end{array}$ & $\begin{array}{l}\text { upper } \\
\text { bound } \\
\text { (mm) }\end{array}$ & & \\
\hline \multirow{2}{*}{ SLA } & $>1 \mathrm{~mm}$ & 0.89 & 0.09 & 0.69 & 1.07 & NS & 142 \\
\hline & $<1 \mathrm{~mm}$ & 1.64 & 0.27 & 1.10 & 2.17 & NS & 50 \\
\hline \multirow{2}{*}{ TPS } & $>1 \mathrm{~mm}$ & 1.37 & 0.11 & 1.15 & 1.59 & NS & 139 \\
\hline & $<1 \mathrm{~mm}$ & 1.75 & 0.21 & 1.35 & 2.16 & $<0.05$ & 55 \\
\hline
\end{tabular}

* A statistically significant association occurred for TPS-surfaced implants with a VBL less than $1 \mathrm{~mm}(p<0.05)$.

Table 19. Combination of implant location (anterior versus posterior arch) and width of vestibular bone lamella (VBL $<1 \mathrm{~mm}$ or VBL $>$ $1 \mathrm{~mm}$ ) in relation to mean bone loss.

\begin{tabular}{|c|c|c|c|c|c|c|c|}
\hline \multirow[b]{2}{*}{$\begin{array}{c}\text { Arch } \\
\text { location* }\end{array}$} & \multirow[b]{2}{*}{$\begin{array}{c}\text { Vestibular } \\
\text { bone } \\
\text { lamella* }\end{array}$} & \multirow[b]{2}{*}{$\begin{array}{l}\text { Mean bone } \\
\text { loss }(\mathrm{mm})\end{array}$} & \multirow[b]{2}{*}{$\begin{array}{l}\text { Standard } \\
\text { error }(\mathrm{mm})\end{array}$} & \multicolumn{2}{|c|}{$\begin{array}{c}95 \% \text { confidence } \\
\text { interval }\end{array}$} & \multirow[b]{2}{*}{$p$-value } & \multirow[b]{2}{*}{$n$} \\
\hline & & & & $\begin{array}{c}\text { lower } \\
\text { bound } \\
(\mathrm{mm})\end{array}$ & $\begin{array}{c}\text { upper } \\
\text { bound } \\
(\mathrm{mm})\end{array}$ & & \\
\hline \multirow{2}{*}{ Posterior } & $>1 \mathrm{~mm}$ & 0.98 & 0.09 & 0.80 & 1.15 & NS & 202 \\
\hline & $<1 \mathrm{~mm}$ & 1.60 & 0.15 & 1.31 & 1.89 & NS & 75 \\
\hline \multirow{2}{*}{ Anterior } & $>1 \mathrm{~mm}$ & 1.28 & 0.12 & 1.04 & 1.51 & NS & 72 \\
\hline & $<1 \mathrm{~mm}$ & 1.79 & 0.31 & 1.19 & 2.39 & $<0.05$ & 30 \\
\hline
\end{tabular}

* A statistically significant association occurred for anterior implants with a VBL less than $1 \mathrm{~mm}(p<0.05)$.

Table 20. Combination of width of vestibular bone lamella (VBL $>1 \mathrm{~mm}$ or $\mathrm{VBL}<1 \mathrm{~mm}$ ) and smoking status in relation to mean bone loss.

\begin{tabular}{|c|c|c|c|c|c|c|c|}
\hline \multirow{2}{*}{$\begin{array}{c}\text { Smoking } \\
\text { status* }\end{array}$} & $\begin{array}{c}\text { Vestibular } \\
\text { bone } \\
\text { lamella* }\end{array}$ & $\begin{array}{c}\text { Mean bone } \\
\text { loss }(\mathrm{mm})\end{array}$ & $\begin{array}{c}\text { Standard } \\
\text { error }(\mathrm{mm})\end{array}$ & \multicolumn{2}{|c|}{$\begin{array}{c}95 \% \text { confidence interval } \\
\text { lower } \\
\text { bound }(\mathrm{mm})\end{array}$} & $\begin{array}{c}\text { upper } \\
\text { bound }(\mathrm{mm})\end{array}$ & $p$-value \\
\hline \multirow{2}{*}{ Non-smoking } & $>1 \mathrm{~mm}$ & 1.08 & 0.08 & 0.93 & 1.24 & NS & 219 \\
\cline { 2 - 8 } & $<1 \mathrm{~mm}$ & 1.14 & 0.11 & 0.92 & 1.36 & NS & 88 \\
\hline \multirow{2}{*}{ Smoking } & $>1 \mathrm{~mm}$ & 1.17 & 0.13 & 0.92 & 1.42 & NS & 55 \\
\cline { 2 - 8 } & $<1 \mathrm{~mm}$ & 2.25 & 0.32 & 1.61 & 2.88 & $<0.05$ & 17 \\
\hline
\end{tabular}

* A statistically significant association occurred in smoker patients with a VBL less than $1 \mathrm{~mm}(P<0.05)$. 
Table 21. Combination of smoking status and height of the smooth collar (esthetic versus standard) in assessing mean bone loss. Although considered alone, the height of the smooth collar did not influence bone loss, the combination of a standard collar with smoking increased bone loss. Values were not significant.

\begin{tabular}{|c|c|c|c|c|c|c|}
\hline \multirow{2}{*}{$\begin{array}{c}\text { Smoking } \\
\text { status* }\end{array}$} & $\begin{array}{c}\text { Height of the } \\
\text { smooth collar* }\end{array}$ & $\begin{array}{c}\text { Mean bone } \\
\text { loss }(\mathrm{mm})\end{array}$ & $\begin{array}{c}\text { Standard } \\
\text { error }(\mathrm{mm})\end{array}$ & $\begin{array}{c}\text { 95\% confidence interval } \\
\text { lower bound } \\
\text { (mm) }\end{array}$ & $\begin{array}{c}\text { upper bound } \\
\text { (mm) }\end{array}$ & $n$ \\
\hline \multirow{2}{*}{ Non-smoking } & esthetic & 0.51 & 0.38 & -0.25 & 1.27 & 52 \\
\cline { 2 - 7 } & standard & 0.87 & 0.16 & 0.55 & 1.19 & 250 \\
\hline \multirow{2}{*}{ Smoking } & esthetic & 1.04 & 0.27 & 0.52 & 1.56 & 14 \\
\cline { 2 - 7 } & standard & 1.77 & 0.21 & 1.36 & 2.18 & 60 \\
\hline
\end{tabular}

* No statistically significant difference found when evaluating the smoking status and the height of the smooth collar $p=0.868$.

Table 22. Combination of smoking status and opposing occlusion (natural/fixed or N/F, removable or mixed) in assessing mean bone loss. The opposing occlusion seemed to induce higher bone loss in a smoker than in a non-smoker. A natural/fixed or mixed opposing occlusion caused higher mean bone loss than a removable one.

\begin{tabular}{|c|c|c|c|c|c|c|}
\hline $\begin{array}{l}\text { Smoking } \\
\text { status* }\end{array}$ & $\begin{array}{l}\text { Opposing } \\
\text { dentition* }\end{array}$ & $\begin{array}{l}\text { Mean bone } \\
\text { loss }(\mathrm{mm})\end{array}$ & $\begin{array}{l}\text { Standard } \\
\text { error }(\mathrm{mm})\end{array}$ & $\begin{array}{l}95 \% \text { co } \\
\text { lower bound } \\
(\mathrm{mm})\end{array}$ & $\begin{array}{l}\text { interval } \\
\text { upper bound } \\
\quad(\mathrm{mm})\end{array}$ & $n$ \\
\hline \multirow{3}{*}{ Non-smoking } & $N / F$ & 0.82 & 0.15 & 0.52 & 1.12 & 227 \\
\hline & removable & 0.58 & 0.41 & -0.22 & 1.38 & 60 \\
\hline & mixed & 0.86 & 0.32 & 0.23 & 1.49 & 14 \\
\hline \multirow{3}{*}{ Smoking } & $\mathrm{N} / \mathrm{F}$ & 1.24 & 0.13 & 0.98 & 1.49 & 64 \\
\hline & removable & 1.01 & 0.35 & 0.31 & 1.70 & 8 \\
\hline & mixed & 3.39 & 0.70 & 2.02 & 4.77 & 3 \\
\hline
\end{tabular}

* No statistically significant difference found when evaluating the smoking status and the opposing dentition $p=0.928$.

Table 23. Combination of height of the smooth collar (esthetic versus standard) and opposing occlusion (natural/fixed (N/F), removable or mixed) in assessing mean bone loss. The standard height of the smooth collar caused generally higher bone loss and this bone loss was higher when the occlusion is natural/fixed or mixed.

\begin{tabular}{|c|c|c|c|c|c|c|}
\hline \multirow[b]{2}{*}{$\begin{array}{l}\text { Height of the } \\
\text { smooth } \\
\text { collar* }\end{array}$} & \multirow[b]{2}{*}{$\begin{array}{l}\text { Opposing } \\
\text { dentition* }\end{array}$} & \multirow[b]{2}{*}{$\begin{array}{l}\text { Mean bone } \\
\text { loss }(\mathrm{mm})\end{array}$} & \multirow[b]{2}{*}{$\begin{array}{l}\text { Standard } \\
\text { error }(\mathrm{mm})\end{array}$} & \multicolumn{2}{|c|}{ 95\% confidence interval } & \multirow[b]{2}{*}{$n$} \\
\hline & & & & $\begin{array}{c}\text { lower bound } \\
(\mathrm{mm})\end{array}$ & $\begin{array}{l}\text { upper bound } \\
(\mathrm{mm})\end{array}$ & \\
\hline \multirow{3}{*}{ Esthetic } & $\mathrm{N} / \mathrm{F}$ & 0.86 & 0.22 & 0.43 & 1.28 & 64 \\
\hline & removable & 0.016 & 0.99 & -1.95 & 1.95 & 2 \\
\hline & mixed & NA & NA. & NA. & NA. & 0 \\
\hline \multirow{3}{*}{ Standard } & $\mathrm{N} / \mathrm{F}$ & 1.11 & 0.08 & 0.95 & 1.27 & 227 \\
\hline & removable & 0.91 & 0.26 & 0.39 & 1.43 & 67 \\
\hline & mixed & 1.71 & 0.32 & 1.08 & 2.33 & 16 \\
\hline
\end{tabular}

* No statistically significant difference found when evaluating the height of the smooth collar and the opposing dentition $p=0.452$.

Table 24. Combination of smoking status and implant location (maxilla versus mandible) in assessing mean bone loss. An implant located in the mandible and placed in a smoker caused higher bone loss.

\begin{tabular}{|c|c|c|c|c|c|c|}
\hline \multirow{2}{*}{$\begin{array}{c}\text { Smoking } \\
\text { status* }\end{array}$} & Jaw* & $\begin{array}{c}\text { Mean bone } \\
\text { loss }(\mathrm{mm})\end{array}$ & $\begin{array}{c}\text { Standard } \\
\text { error }(\mathrm{mm})\end{array}$ & \multicolumn{2}{|c|}{$\begin{array}{c}\text { 95\% confidence interval } \\
\text { lower bound } \\
(\mathrm{mm})\end{array}$} & $\begin{array}{c}\text { upper bound } \\
\text { (mm) }\end{array}$ \\
\hline \multirow{2}{*}{ Non-smoking } & maxilla & 0.74 & 0.23 & 0.28 & 1.19 & 118 \\
\cline { 2 - 7 } & mandible & 0.75 & 0.24 & 0.29 & 1.23 & 187 \\
\hline \multirow{2}{*}{ Smoking } & maxilla & 1.06 & 0.17 & 0.71 & 1.39 & 34 \\
\cline { 2 - 7 } & mandible & 2.01 & 0.27 & 1.48 & 2.53 & 47 \\
\hline
\end{tabular}

* No statistically significant difference found when evaluating the smoking status and the implant location $p=0.652$. 
Table 25. Combination of different implant lengths $(\mathrm{mm})$ and smoking status in assessing mean bone loss. No correlation was observed.

\begin{tabular}{|c|c|c|c|c|c|c|}
\hline $\begin{array}{l}\text { Smoking } \\
\text { status* }\end{array}$ & Length* & $\begin{array}{l}\text { Mean bone } \\
\text { loss }(\mathrm{mm})\end{array}$ & $\begin{array}{l}\text { Standard } \\
\text { error }(\mathrm{mm})\end{array}$ & $\begin{array}{l}95 \% \mathrm{co} \\
\text { lower bound } \\
(\mathrm{mm})\end{array}$ & $\begin{array}{l}\text { interval } \\
\text { upper bound } \\
(\mathrm{mm})\end{array}$ & $n$ \\
\hline \multirow{7}{*}{ Non-smoking } & $6 \mathrm{~mm}$ & 1.22 & 0.67 & -1.05 & 2.54 & 4 \\
\hline & $8 \mathrm{~mm}$ & 1.01 & 0.23 & 0.57 & 1.45 & 61 \\
\hline & $9 \mathrm{~mm}$ & 0.48 & 0.55 & -0.60 & 1.56 & 6 \\
\hline & $10 \mathrm{~mm}$ & 1.37 & 0.16 & 1.05 & 1.69 & 81 \\
\hline & $11 \mathrm{~mm}$ & 1.39 & 0.33 & 0.73 & 2.05 & 25 \\
\hline & $12 \mathrm{~mm}$ & 1.08 & 0.27 & 0.56 & 1.61 & 69 \\
\hline & $13 \mathrm{~mm}$ & 0.98 & 0.52 & -0.05 & 2.00 & 6 \\
\hline
\end{tabular}

* No statistically significant difference found when evaluating the smoking status and the implant length $p=0.945$.

\begin{tabular}{|c|c|c|c|c|c|c|}
\hline $\begin{array}{l}\text { Smoking } \\
\text { status* }\end{array}$ & Length* & $\begin{array}{l}\text { Mean bone } \\
\text { loss }(\mathrm{mm})\end{array}$ & $\begin{array}{c}\text { Standard } \\
\text { error }(\mathrm{mm})\end{array}$ & $\begin{array}{r}95 \% \mathrm{co} \\
\begin{array}{l}\text { lower bound } \\
(\mathrm{mm})\end{array}\end{array}$ & $\begin{array}{l}\text { interval } \\
\text { upper bound } \\
(\mathrm{mm})\end{array}$ & $n$ \\
\hline \multirow{7}{*}{ Smoking } & $6 \mathrm{~mm}$ & 1.46 & 0.67 & 0.14 & 2.78 & 5 \\
\hline & $8 \mathrm{~mm}$ & 1.63 & 0.39 & 0.87 & 2.39 & 11 \\
\hline & $9 \mathrm{~mm}$ & 1.16 & 0.67 & -0.17 & 2.48 & 8 \\
\hline & $10 \mathrm{~mm}$ & 1.85 & 0.24 & 1.39 & 2.31 & 30 \\
\hline & $11 \mathrm{~mm}$ & 0.98 & 0.41 & 0.17 & 1.79 & 6 \\
\hline & $12 \mathrm{~mm}$ & 1.07 & 0.28 & 0.50 & 1.63 & 14 \\
\hline & $13 \mathrm{~mm}$ & 0.99 & 0.53 & -0.03 & 2.32 & 60 \\
\hline
\end{tabular}

Table 26. Percentage distribution of TPS/SLA-surfaced implants in relation to crestal bone loss and "supra-boundary bone" groups. The Pearson Square test $p$-value indicates the significance of the correlation of this factor to CBL or "supra-boundary bone" $(p<0.05)$.

\begin{tabular}{|c|c|c|c|c|}
\hline $\begin{array}{l}\text { Mean CBL (mm) and } \\
\text { "supra-boundary bone" }\end{array}$ & \multicolumn{4}{|c|}{ Surface } \\
& SLA (\%) & $n$ & TPS (\%) & $n$ \\
\hline$>3$ & 2.0 & 4 & 11.9 & 23 \\
\hline $2-3$ & 6.2 & 12 & 9.3 & 18 \\
\hline $1-2$ & 27.2 & 52 & 27.8 & 54 \\
\hline $0-1$ & 56.7 & 109 & 41.7 & 81 \\
\hline "supra-boundary bone" & 7.8 & 15 & 9.3 & 18 \\
\hline TOTAL & 100 & 192 & 100 & 194 \\
\hline
\end{tabular}

$b_{0}=$ constant, $b_{1}, b_{2}, b_{3}=$ regression coefficients, $R=$ correlation coefficient, $R^{2}=$ percentage of explained variance.

Pearson Chi square test confirmed the significance $(p<$ 0.05) of each investigated factor (mentioned above). All the other factors were not found to be statistically significant.

\section{Effect of combined factors on mean $\mathrm{CBL}$}

Implants with different lengths and widths, different heights of the smooth collar, different jaw locations, having a removable or fixed suprastructure, having fixed, removable or mixed opposing dentitions, and at different distances from the adjacent teeth/implants did not show a significant influence on mean bone levels, even when combined with other factors in the current study.

An ANOVA univariate analysis test was used to evaluate the effect of a combination of different factors on mean $\mathrm{CBL}$. Interesting correlations were noted when combining factors that had already individually shown to have a statistically significant impact on mean CBL For example, the combination of a smoking subject and TPS-surfaced implant resulted in a higher bone loss than each parameter independently (Tables 14-20).

Moreover, the combination of not statistically significant factors with statistically significant ones was performed. Some interesting correlations were noted, but results were not significant (Tables 21-30)

The influence of the statistically significant parameters on 5 subgroups of bone change

Parameters with significant influence on peri-implant bone change according to ANOVA were then distributed into 5 subgroups (Fig. 11 and Tables 26-31). These groups were also divided according to implant length, although this was not a statistically significant factor. 
Table 27. Percentage distribution of anterior/posterior implants in relation to crestal bone loss and "supra-boundary bone" groups. The Pearson Square test $p$-value indicates the significance of the correlation of this factor to CBL or "supra-boundary bone" $(p<0.05)$.

\begin{tabular}{|c|c|c|c|c|}
\hline $\begin{array}{c}\text { Mean CBL (mm) and } \\
\text { "supra-boundary bone" }\end{array}$ & anterior (\%) & $n$ & prch location & $n$ \\
\hline$>3$ & 11.3 & 15 & 5.4 & 12 \\
\hline $2-3$ & 12.4 & 17 & 6.1 & 13 \\
\hline $1-2$ & 26.5 & 28 & 27.9 & 78 \\
\hline $0-1$ & 48.0 & 51 & 49.7 & 139 \\
\hline "supra-boundary bone" & 1.8 & 2 & 5.3 & 31 \\
\hline TOTAL & 100 & 106 & 100 & 280 \\
\hline
\end{tabular}

Table 28. Percentage distribution of the implants placed in smoker/non-smoker patients in relation to crestal bone loss and "supra-boundary bone" groups. The Pearson Square test $p$-value indicated the significance of the correlation of this factor to CBL or "supra-boundary bone" $(p<0.05)$.

\begin{tabular}{|c|c|c|c|c|}
\hline $\begin{array}{c}\text { Mean CBL (mm) and } \\
\text { "supra-boundary bone" }\end{array}$ & \multicolumn{3}{|c|}{ Smoking status } \\
\hline smoking (\%) & $n$ & non-smoking (\%) & $n$ \\
\hline $2-3$ & 9 & 9 & 11.6 & 18 \\
\hline $1-2$ & 9 & 9 & 11.6 & 21 \\
\hline $0-1$ & 21 & 21 & 27.1 & 85 \\
\hline "supra-boundary bone" & 37 & 37 & 48.2 & 153 \\
\hline TOTAL & 1 & 1 & 10.4 & 32 \\
\hline
\end{tabular}

Table 29. Percentage distribution of the percentage of implants with a vestibular bone lamella either less than or greater than $1 \mathrm{~mm}$ in relation to crestal bone loss and "supra-boundary bone" groups. The Pearson Square test p-value indicates the significance of the correlation of this factor to CBL or "supra-boundary bone" $(p<0.05)$.

\begin{tabular}{|c|c|c|c|c|}
\hline $\begin{array}{c}\text { Mean CBL (mm) and } \\
\text { "supra-boundary bone" }\end{array}$ & $>1 \mathrm{~mm}(\%)$ & $n$ & $<1 \mathrm{~mm}(\%)$ & $n$ \\
\hline$>3$ & 3.6 & 10 & 16.2 & 17 \\
\hline $2-3$ & 7.8 & 22 & 2.7 & 8 \\
\hline $1-2$ & 29.2 & 82 & 50.4 & 24 \\
\hline $0-1$ & 48.8 & 137 & 30 & 5 \\
\hline "supra-boundary bone" & 10.7 & 281 & 100 & 3 \\
\hline TOTAL & 100 & & & 105 \\
\hline
\end{tabular}

Table 30. Percentage distribution of implants according to different lengths $(6,8,9,10,11,12$ and $13 \mathrm{~mm})$ in relation to crestal bone loss and "supra-boundary bone" groups. The Pearson Square test $p$-value indicates the non-significant correlation of this factor to CBL or "supra-boundary bone" ( $p=0.458)$.

\begin{tabular}{|c|c|c|c|c|c|c|c|c|}
\hline \multirow{2}{*}{$\begin{array}{l}\text { Mean CBL and } \\
\text { “supra-boundary } \\
\text { bone" (mm) }\end{array}$} & \multicolumn{7}{|c|}{ Length } & \multirow{2}{*}{$n$ total } \\
\hline & $\begin{array}{c}6 \mathrm{~mm} \\
(\%)\end{array}$ & $\begin{array}{c}8 \mathrm{~mm} \\
(\%)\end{array}$ & $\begin{array}{c}9 \mathrm{~mm} \\
(\%)\end{array}$ & $\begin{array}{c}10 \mathrm{~mm} \\
(\%)\end{array}$ & $\begin{array}{c}11 \mathrm{~mm} \\
(\%)\end{array}$ & $\begin{array}{c}12 \mathrm{~mm} \\
(\%)\end{array}$ & $\begin{array}{c}13 \mathrm{~mm} \\
(\%)\end{array}$ & \\
\hline$>3$ & $0.0(n=0)$ & $16(n=5)$ & $0.0(n=0)$ & $7.9(n=12)$ & $9.2(n=4)$ & $6.6(n=6)$ & $0.0(n=0)$ & 27 \\
\hline $2-3$ & $30(n=1)$ & $16(n=5)$ & $18.8(n=1)$ & $6.6(n=10)$ & $9.2(n=4)$ & $7.4(n=7)$ & $34.5(n=2)$ & 30 \\
\hline $1-2$ & $30(n=1)$ & $36.5(n=22)$ & $31.3(n=2)$ & $29.2(n=44)$ & $21.1(n=9)$ & $29.9(n=28)$ & $0.0(n=0)$ & 106 \\
\hline $0-1$ & $30(n=4)$ & $11.4(n=39)$ & $31.3(n=2)$ & $48.3(n=73)$ & $59.6(n=25)$ & $48.8(n=46)$ & $65.5(n=4)$ & 190 \\
\hline "supra-boundary bone" & $40(n=4)$ & $21.4(n=12)$ & $18.8(n=1)$ & $7.9(n=12)$ & $0.0(n=0)$ & $7.4(n=7)$ & $0.0(n=0)$ & 33 \\
\hline TOTAL & $100(n=4)$ & $100(n=83)$ & $100(n=6)$ & $100(n=151)$ & $100(n=42)$ & $100(n=94)$ & $100(n=6)$ & 386 \\
\hline
\end{tabular}


Table 31. Percentage distribution of implant-implant or implant-tooth distances in relation to bone loss and 'supra-boundary bone' groups. The Pearson Square test $p$-value indicates a non-significant association between this factor and CBL or 'supra-boundary bone' $(p=0.951)$.

\begin{tabular}{|c|c|c|c|c|c|}
\hline $\begin{array}{c}\text { Mean CBL and } \\
\text { "supra-boundary bone" (mm) }\end{array}$ & $\begin{array}{c}1-2 \mathrm{~mm} \\
(\%)\end{array}$ & $\begin{array}{c}2-3 \mathrm{~mm} \\
(\%)\end{array}$ & $\begin{array}{c}3-4 \mathrm{~mm} \\
(\%)\end{array}$ & $\begin{array}{c}>4 \mathrm{~mm} \\
(\%)\end{array}$ & Total \\
\hline$>3$ & $5.8(n=7)$ & $8.6(n=10)$ & $9.1(n=4)$ & $6.2(n=5)$ & 27 \\
\hline $2-3$ & $8.9(n=3)$ & $8.6(n=25)$ & $14.5(n=9)$ & $3.9(n=18)$ & 30 \\
\hline $1-2$ & $30.5(n=8)$ & $23.7(n=36)$ & $14.5(n=6)$ & $32.6(n=41)$ & 106 \\
\hline $0-1$ & $46.3(n=9)$ & $49.4(n=56)$ & $47.3(n=37)$ & $47.3(n=47)$ & 183 \\
\hline "supra-boundary bone" & $8.2(n=6)$ & $9.8(n=24)$ & $14.5(n=10)$ & $10.1(n=25)$ & 33 \\
\hline TOTAL & $100(n=33)$ & $100(n=151)$ & $100(n=66)$ & $100(n=136)$ & 379 \\
\hline
\end{tabular}

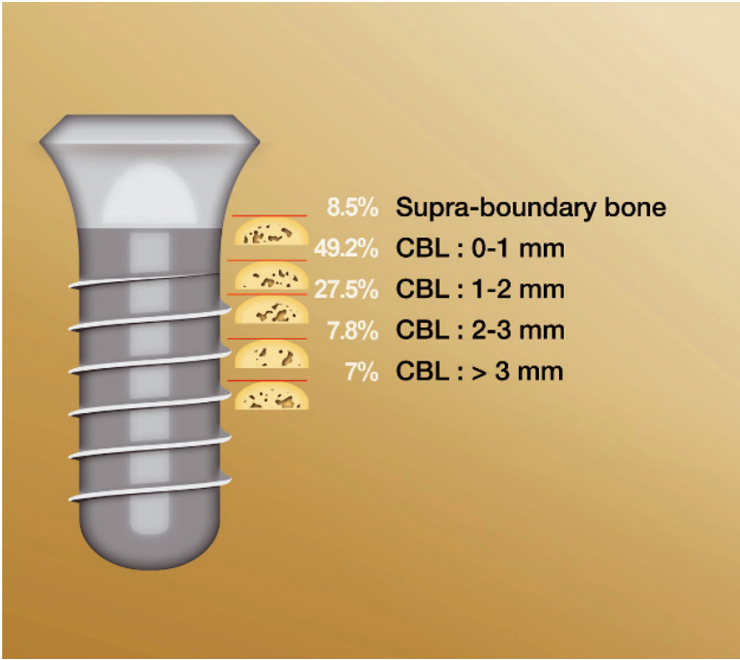

Fig. 11. Five subgroups of bone change.

\section{References}

1. Lang NP, Wilson TG, Corbet EF. Biological complications with dental implants: their prevention, diagnosis and treatment. Clin Oral Implants Res 2000;11 Suppl 1:146-55.

2. Brånemark PI, Zarb GA, Albrektsson T. Tissue-integrated prostheses (pp 129-43). Quintessence, Chicago, 1985.

3. Adell R, Lekholm U, Rockler B, Brånemark PI. A 15-year study of osseointegrated implants in the treatment of the edentulous jaw. Int J Oral Surg 1981;10:387-416.

4. Adell R, Lekholm U, Rockler B, Brånemark PI, Lindhe J, Eriksson $B$, Sbordone L. Marginal tissue reactions at osseointegrated titanium fixtures (I). A 3-year longitudinal prospective study. Int J Oral Maxillofacial Surg 1986;15:39-52.

5. Alberktsson T, Zarb G, Worthington P, Eriksson AR. The long-term efficacy of currently used dental implants: a review and proposed criteria of success. Int J Oral Maxillofac Implants 1986;1:11-25.

6. De Smet E, Jacobs R, Gijbels F, Naert I. The accuracy and reliability of radiographic methods for the assessment of marginal bone level around oral implants. Dentomaxillofac Radiol 2002;31:176-81.

7. Buser D, Weber HP, Lang NP. Tissue integration of nonsubmerged implants. 1-year results of a prospective study with 100 ITI hollow-cylinder and hollow-screw implants. Clin Oral Implants Res 1990;1:33-40.
8. Hermann JS, Buser D, Schenk RK, Cochran DL. Crestal bone changes around titanium implants. A histometric evaluation of unloaded non-submerged and submerged implants in the canine mandible. J Periodentol 2000;71:1412-24.

9. Hermann JS, Schoolfield JD, Nummikoski PV, Buser D, Schenk RK, Cochran DL. Crestal bone changes around titanium implants: a methodological study comparing linear radiographic with histometric measurements. Int J Oral Maxillofac Implants 2001;16:475-85.

10. Hermann JS, Schoolfield JD, Schenk RK, Buser D, Cochran DL. Influence of the size of the microgap on crestal bone changes around titanium implants. A histometric evaluation of unloaded non-submerged implants in the canine mandible. J Periodontol 2001;72:1372-83.

11. Hermann JS, Cochran DL, Nummikoski PV, Buser D. Crestal bone changes around titanium implants. A radiographic evaluation of unloaded nonsubmerged and submerged implants in the canine mandible. J Periodontol 1997;68:1117-30.

12. Berglundh $T$, Persson $L$, Klinge B. A systematic review of the incidence of biological and technical complications in implant dentistry reported in prospective longitudinal studies of at least 5 years. J Clin Periodontal 2002;29 Suppl 3:197-212. 232-3.

13. Brägger U, Hugel-Pisoni C, Burgin W, Buser D, Correlations between radiographic, clinical and mobility parameters after loading of oral implants with fixed partial dentures. A 2-year longitudinal study. Clin Oral Implant Res 1996;7:230-9.

14. Zechner W, Trinkl N, Watzak G, Busenlechner D, Tepper G, Haas R, Watzek $G$. Radiologic follow-up of peri-implant bone loss around machine-surfaced and rough-surfaced interforaminal implants in the mandible functionally loaded for 3 to 7 years. Int $\mathrm{J}$ Oral Maxillofac Implants 2004;19:216-21.

15. Zybutz M, Rapoport D, Laurell L, Persson GR. Comparisons of clinical and radiographic measurements of inter-proximal vertical defects before and 1 year after surgical treatments. J Clin Periodontol 2000;27:179-86.

16. Weber HP, Crohin CC, Fiorellini JP. A 5-year prospective clinical and radiographic study of non-submerged dental implants. Clin Oral Implants Res 2000;11:144-53.

17. Wyatt CC, Zarb GA. Bone level changes proximal to oral implants supporting fixed partial prostheses. Clin Oral Implants Res 2002;13:162-8.

18. Fransson C, Lekholm U, Jemt T, Berglundh T. Prevalence of subjects with progressive bone loss at implants. Clin Oral Implants Res 2005;16:440-6.

19. Wenntröm J, Palmer R. Consensus report of session 3: clinical trails (pp 255-9). Proceedings of the $3^{\text {rd }}$ European workshop on Periodontolgy. Implant Dentistry. Lang N, Karring T, Lindhe J eds. Quintessence, Berlin, 1999. 
20. Jemt T, Lekholm U. Oral implant treatment in posterior partially edentulous jaws: a 5-year follow-up report. Int J Oral Maxillofac Implants 1993;8:635-40.

21. Buser D, Mericske-Stern R, Bernard JP, Behneke A, Behneke N, Hirt HP, Belser UC, Lang NP. Long-term evaluation of nonsubmerged. ITI implants. Part 1: 8-year life table analysis of a prospective multi-center study with 2359 implants. Clin Oral Implants Res 1997;8:161-172.

22. Snauwaert K, Duyck J, van Steenberghe D, Quirynen M, Naert I. Time dependent failure rate and marginal bone loss of implant supported prostheses: a 15-year follow-up study. Clin Oral Investig 2000;4:13-20.

23. Mombelli A, Lang NP. The diagnosis and treatment of periimplantitis. Periodontol 2000 1998;17:63-76.

24. Lindquist LW, Carlsson GE, Jemt T. A prospective 15-year followup study of mandibular fixed prostheses supported by osseointegrated implants. Clinical results and marginal bone loss. Clin Oral Implants Res 1996;7:329-36.

25. Grondahl K, Sunden S, Grondahl HG. Inter- and intraobserver variability in radiographic bone level assessment at Brånemark fixtures. Clin Oral Implants Res 1998;4:243-50.

26. Lee JH, Frias V, Lee KW, Wright RF. Effect of implant size and shape on implant success rates: a literature review. Prosthet Dent 2005;94:377-81.

27. Hämmerle $\mathrm{CH}$, Brägger $\mathrm{U}$, Burgin W, Lang NP. The effect of subcrestal placement of the polished surface of ITI implants on marginal soft and hard tissues. Clin Oral Implants Res 1996;7:111-9.

28. Hartmann GA, Cochran DL. Initial implant position determines the magnitude of crestal bone remodeling. J Periodontol 2004; 75:572-7.

29. Bernard JP, Belser UC, Martinet JP, Borgis SA. Osseointegration of Brånemark fixtures using a single-step operating technique. A preliminary prospective one-year study in the edentulous mandible. Clin Oral Implants Res 1995;6:122-9.

30. Pepelassi EA, Diamanti-Kipioti A. Selection of the most accurate method of conventional radiography for the assessment of periodontal osseous destruction. J Clin Periodontol 2000;27:179-86.

31. Romeo E, Lops D, Amorfini L, Chiapasco M, Ghisolfi M, Vogel G. Clinical and radiographic evaluation of small-diameter $(3.3-\mathrm{mm})$ implants followed for 1-7 years: a longitudinal study. Clin Oral Implants Res 2006;17:139-48.

32. Rosling B, Hollender L, Nyman S, Olsson G. A radiographic method for assessing changes in alveolar bone height following periodontal therapy. J Clin Periodontol 1975;2:211-7.

33. Zechner W, Watzak G, Gahleitner A, Busenlechner D, Tepper G, Watzek G. Rotational panoramic versus intraoral rectangular radiographs for evaluation of peri-implant bone loss in the anterior atrophic mandible. Int J Oral Maxillofac Implants 2003;18:8738.

34. Sewerin IP. Errors in radiographic assessment of marginal bone height around osseointegrated implants. Scand J Dent Res 1990;98:428-33.

35. Benn DK. Limitations of the digital image subtraction technique in assessing alveolar bone crest changes due to misalignment errors during image capture. Dentomaxillofac Radiol 1990;19:97-104.

36. Wahl G, Lang H. Deformation at the implant interface to prosthetic superstructure: an interferometric approach. Clin Oral Implants Res 2004;15:233-8.
37. Spiekermann H, Jansen VK, Richter EJ. A 10-year follow-up study of IMZ and TPS implants in the edentulous mandible using bar-retained overdentures. Int J Oral Maxillofac Implants 1995; 10:231-43.

38. Quirynen M, van Steenberghe D, Jacobs R, Schotte A, Darius P. The reliability of pocket probing around screw-type implants. Clin Oral Implants Res 1991;2:186-92.

39. Isidor F. Clinical probing and radiographic assessment in relation to the histologic bone level at oral implants in monkeys. Clin Oral Implants Res 1997;8:255-64.

40. Ericsson I, Lindhe J. Probing depth at implants and teeth. An experimental study in the dog. J Clin Periodontol 1993;20:6237.

41. Akesson L, Hakansson J, Rohlin M. Comparison of panoramic and intraoral radiography and pocket probing for the measurement of the marginal bone level. J Clin Periodontol 1992;19:326-32.

42. Lofthag-Hansen S, Lindh C, Petersson A. Radiographic assessment of the marginal bone level after implant treatment: a comparison of periapical and Scanora detailed narrow beam radiography. Dentomaxillofac Radiol 2003;32:97-103.

43. Battenberg RH, Meijer HJ, Raghoebar GM, Van Port RP, Boering G. Mandibular overdentures supported by two Brånemark, IMZ or ITI implants. A prospective comparative preliminary study: one-year results. Clin Oral Implants Res 1998;9:374-383.

44. Fiorellini JP, Buser D, Paquette DW, Williams RC, Haghighi D, Weber HP. A radiographic evaluation of bone healing around submerged and non-submerged dental implants in beagle dogs. J Periodontol 1999;70:248-54.

45. Heydenrijk K, Raghoebar GM, Meijer HJ, Stegenga B. Clinical and radiologic evaluation of 2-stage IMZ implants placed in a single-stage procedure: 2-year results of a prospective comparative study. Int J Oral Maxillofac Implants 2003;18:424-32.

46. Karoussis K, Muller S, Salvi G, Heitz-Mayfield L, Brägger U, Lang N. Association between periodontal and peri-implant conditions ; a 10 year prospective study. Clin Oral Impl Res 2004;15:1-7.

47. Meijer HJ, Heijdenrijk K, Raghoebar GM. Mucosal and radiographic aspects during the healing period of implants placed in a one-stage procedure. Int J Prosthodont 2003;16:397-402.

48. Mericske-Stern R, Oetterli M, Kiener P, Mericske E. A follow-up study of maxillary implants supporting overdentures. clinical and radiographic results. Int J Oral Maxillofac Implants 2002;17:67886.

49. Penarrocha M, Palomar M, Sanchis JM, Guarinos J, Balaguer J. Radiologic study of marginal bone loss around 108 dental implants and its relationship to smoking, implant location, and morphology. Int J Oral Maxillofac Implants 2004;19:861-78.

50. Romeo E, Ghisolfi M, Rozza R, Chiapasco M, Lops D. Short (8mm) dental implants in the rehabilitation of partial and complete edentulism: a 3 to 14 year longitudinal study. Int J Prosthodont 2006;19:586-92.

51. Blanes RJ, Bernard JP, Blanes ZM, Belser UC. A 10-year prospective study of ITI dental implants placed in the posterior region: I Clinical and radiographic results. Clin Oral Implants Res 2007;18:699-706.

52. Von Wowern N. In vivo measurement of bone mineral content of mandibles by dual photon absoptiometry. Scand J Dent Res 1985;93:162-8.

53. Brägger U, Pasquali L, Kornman KS. Remodeling of interdental alveolar bone after periodontal flap procedures assessed 
by means of computer-assisted densitometric image analysis (CADIA). J Clin Periodontol 1988;15:558-4.

54. Cochran DL, Hermann JS, Schenk RK, Higginbottom FL, Buser D. Biologic width around titanium implants. A histometric analysis of the implanto-gingival junction around unloaded and loaded nonsubmerged implants in the canine mandible. J Periodontol 1997;68:186-98.

55. Smith DE, Zarb GA. Criteria for success of osseointegrated endosseous implants. J Prosthet Dent 1989;62:567-72.

56. Abrahamsson I, Zitzmann NU, Berglundh T, Wennerberg A, Lindhe J. Bone and soft tissue integration to titanium implants with different surface topography: an experimental study in the dog. Int J Oral Maxillofac Implants 2001;16:323-33.

57. Meriscke-Stern R, Venetz $E$, Fahrlander $F$, Burgin W. In vivo force measurements on maxillary implants supporting a fixed prosthesis or an overdenture: a pilot study. J Prosthet Dent 2000;84:535-47.

58. Keller W, Brägger U, Mombelli A. Peri-implant microflora of implants with cemented and screw retained suprastructures. Clin Oral Implants Res 1998;9:209-17.

59. Lindquist LW, Carlsson GE, Jemt T. Association between marginal bone loss around osseointegrated mandibular implants and smoking habits: a 10-year follow-up study. J Dent Res 1997;76:1667-74.

60. Lum LB. A biomechanical rationale for the use of short implants. J Oral Implantol 1991;17:126-31.

61. Mailath G, Stoiber B, Watzek G, Matejka M. Bone resorption at the entry of osseointegrated implants - a biomechanical phenomenon. Finite element study. Z Stomatol 1989;86:207-16.

62. Meriscke-Stern R. Force distribution on implants supporting overdentures: the effect of distal bar extensions. A 3-D in vivo study. Clin Oral Implants Res 1997;8:142-51.

63. Miyata T, Kobayashi Y, Araki H, Ohto T, Shin K. The influence of controlled occlusal overload on peri-implant tissue. Part 4: a histologic study in monkeys. Int J Oral Maxillofac Implants 2002;17:384-90.

64. Nedir R, Bischof M, Briaux JM, Beyer S, Szmukler-Moncler S, Bernard JP. A 7-year life table analysis from a prospective study on ITI implants with special emphasis on the use of short implants. Results from a private practice. Clin Oral Implants Res 2004; 15:150-7.

65. Esposito M, Hirsch JM, Lekholm U, Thomsen P. Biological factors contributing to failures of osseointegrated oral implants. (I) Success criteria and epidemiology. Eur J Oral Sci 1998;106:527-51.

66. Nedir R, Bischof M, Szmukler-Moncler S, Belser UC, Samson J. Prosthetic complications with dental implants: from an upto-8-year experience in private practice. Int J Oral Maxillofac Implants 2006;21:919-28.

67. Scharf DR, Tarnow DP. Success rates of osseointegration for implants placed under sterile versus clean conditions. J Periodontol 1993;64:954-6.

68. Buser D, von Arx T. Surgical procedures in partially edentulous patients with ITI implants. Clin Oral Implants Res 2000;11 Suppl 1:83-100.

69. Hämmerle $\mathrm{CH}$, Ingold HP, Lang NP. Evaluation of clinical and radiographic scoring methods before and after initial periodontal therapy. J Clin Periodontol 1990;17:255-63.

70. Arlin ML. Survival and success of sandblasted, large-grit, acidetched and titanium plasma-sprayed implants: a retrospective study. J Can Dent Assoc 2007;73:821.
71. Cochran DL, Buser D, ten Bruggenkate CM, Weingart D, Taylor TM, Bernard JP, Peters F, Simpson JP. The use of reduced healing times on ITI implants with a sandblasted and acid-etched (SLA) surface: early results from clinical trials on ITI SLA implants.Clin Oral Implants Res 2002;13:144-53.

72. Cochran DL, Schenk RK, Lussi A, Higginbottom FL, Buser D.Bone response to unloaded and loaded titanium implants with a sandblasted and acid-etched surface: a histometric study in the canine mandible. J Biomed Mater Res 1998;40:1-11.

73. Bornstein MM, Schmid B, Belser UC, Lussi A, Buser D. Early loading of non-submerged titanium implants with a sandblasted and acid-etched surface. 5 -year results of a prospective study in partially edentulous patients. Clin Oral Implants Res 2005;16:631-8.

74. Roccuzzo M, Wilson TG. A prospective study evaluating a protocol for 6 weeks' loading of SLA implants in the posterior maxilla. Clin Oral Implants Res 2002:13:502-7.

75. DeLuca S, Zarb G. The effect of smoking on osseointegrated dental implants. Part II: Peri-implant bone loss. Int J Prosthodont 2006;19:560-6.

76. Gruica B, Wang HY, Lang NP, Buser D. Impact of IL-1 genotype and smoking status on the prognosis of osseointegrated implants. Clin Oral Implants Res 2004;15:393-400.

77. Carlsson GE, Lindquist LW, Jemt T. Long-term marginal periimplant bone loss in edentulous patients. Int J Prosthodont 2000;13:295-302.

78. Ozkan Y, Ozcan M, Akoglu B, Ucankale M, Kulak-0zkan Y. Threeyear treatment outcomes with three brands of implants placed in the posterior maxilla and mandible of partially edentulous patients. J Prosthet Dent 2007;97:78-84.

79. Quirynen M, Naert I, van Steenberghe D, Nys L. A study of 589 consecutive implants supporting complete fixed prostheses. Part I: Periodontal aspects. J Prosthet Dent 1992;68:655-63.

80. Carmagnola D, Araujo M, Berglundh T, Albrektsson T, Lindhe J. Bone tissue reaction around implants placed in a compromised jaw. J Clin Periodontol 1999;26:629-35.

81. Brägger U, Hafeli U, Huber B, Hammerle CH, Lang NP. Evaluation of postsurgical crestal bone levels adjacent to non-submerged dental implants. Clin Oral Implants Res 1998;9:218-24.

82. Renouard F, Arnoux JP, Sarment DP. Five-mm-diameter implants without a smooth surface collar: report on 98 consecutive placements. Int J Oral Maxillofac Implants 1999;14:101-7.

83. Ivanoff $\mathrm{CJ}$, Grondahl K, Sennerby L, Bergstrom C, Lekholm $U$. Influence of variations in implant diameters: a 3- to 5year retrospective clinical report. Int J Oral Maxillofac Implants 1999;14:173-80.

84. Block MS, Delgado A, Fontenot MG. The effect of diameter and length of hydroxylapatite-coated dental implants on ultimate pullout force in dog alveolar bone. J Oral Maxillofac Surg 1990;48:174-8.

85. Bischof M, Nedir R, Abi Najm S, Szmukler-Moncler S, Samson J. A five-year life-table analysis on wide neck ITI implants with prosthetic evaluation and radiographic analysis: results from a private practice. Clin Oral Implants Res 2006;17:512-20.

86. Tallgren A. The continuing reduction of the residual alveolar ridges in complete denture wearers: a mixed-longitudinal study covering 25 years. J Prosthet Dent 1972;27:120-32.

87. Penarrocha M, Guarinos J, Sanchis JM, Balaguer J. A retrospective study (1994-1999) of $441 \mathrm{ITI}(\mathrm{r})$ implants in 114 patients followed-up during an average of 2.3 years. Med Oral 2002; 7:144-55. 
88. Hanggi MP, Hanggi DC, Schoolfield JD, Meyer J, Cochran DL, Hermann JS. Crestal bone changes around titanium implants. Part I: A retrospective radiographic evaluation in humans comparing two non-submerged implant designs with different machined collar lengths. J Periodontol 2005;76:791-802.

89. Romeo E, Lops D, Margutti E, Ghisolfi M, Chiapasco M, Vogel $G$. Long-term survival and success of oral implants in the treatment of full and partial arches: a 7-year prospective study with the ITI dental implant system. Int J Oral Maxillofac Implants 2004;19:247-59.

90. Kiener P, Oetterli M, Mericske E, Mericske-Stern R. Effectiveness of maxillary overdentures supported by implants: maintenance and prosthetic complications. Int $\mathrm{J}$ Prosthodont 2001;14:133-40.

91. Oetterli M, Kiener P, Mericske-Stern R. A longitudinal study on mandibular implants supporting an overdenture: the influence of retention mechanism and anatomic-prosthetic variables on peri-implant parameters. Int J Prosthodont 2001;14:536-42.

92. Tarnow DP, Cho SC, Wallace SS. The effect of inter-implant distance on the height of inter-implant bone crest. J Periodontol 2000;71:546-9.
93. Ivanoff CJ, Grondahl K, Bergstrom C, Lekholm U, Brånemark PI. Influence of bicortical or monocortical anchorage on maxillary implant stability: a 15-year retrospective study of Brånemark system implants. Int J Oral Maxillofac Implants 2000;15:103-10.

94. Bernard JP, Szmukler-Moncler S, Pessotto S, Vazquez L, Belser UC. The anchorage of Brånemark and ITI implants of different lengths. I. An experimental study in the canine mandible. Clin Oral Implants Res 2003;14:593-600.

95. Deporter D, Todescan R, Caudry S. Simplifying management of the posterior maxilla using short, porous-surfaced dental implants and simultaneous indirect sinus elevation. Int J Periodont Restorat Dent 2000;20:476-85.

96. Renouard F, Nisand D. Short implants in the severely resorbed maxilla: a 2-year retrospective clinical study. Clin Implant Dent Relat Res 2005;7 Suppl 1:104-10.

97. Rokni S, Todescan R, Watson P, Pharoah M, Adegbembo A0, Deporter D. An assessment of crown-to-root ratios with short sintered porous-surfaced implants supporting prostheses in partially edentulous patients. Int $\mathrm{J}$ Oral Maxillofac Implants 2005;20:69-76. 